\title{
Granulito Uyarani - uma janela estrutural Pré-Cambriana no Altiplano Boliviano: petrogênese e significado tectônico
}

\author{
Granulito Uyarani - a Pre-Cambrian structural window at the Bolivian Plateau: \\ petrogenesis and tectonic meaning
}

\author{
Juliana Rezende de Oliveira ${ }^{1,2}$, Maria Zélia Aguiar de Sousa ${ }^{1,2}$, Amarildo Salina Ruiz $^{1,2}$, Gerardo Ramiro Matos Salinas ${ }^{3}$ \\ ${ }^{1}$ Programa de Pós-Graduação em Geociências, Faculdade de Geociências, Universidade Federal de Mato Grosso - UFMT, \\ Avenida Fernando Corrêa da Costa s/n, Coxipó, CEP 78060-900 Cuiabá, MT, BR (ju_azuma@hotmail.com; \\ prof.mzaguiar@gmail.com; asruiz@gmail.com) \\ ${ }^{2}$ Instituto Nacional de Ciência e Tecnologia de Geociências da Amazônia (GEOCIAM), Instituto de Geociências, \\ Universidade Federal do Pará - UFPA, Belém, PA, BR. \\ ${ }^{3}$ Departamento de Geologia, Instituto de Investigaciones Geológicas y del Medio Ambiente - IGEMA, Universidad Mayor de \\ San Andrés - UMSA, San Andrés, La Paz, Bolívia. (rmatoss@yahoo.com)
}

Recebido em 12 de fevereiro de 2016; aceito em 05 de abril de 2017

\begin{abstract}
Resumo
O embasamento pré-andino é formado por terrenos paleoproterozoicos, como o terreno Arequipa-Antofalla, e entre suas unidades destaca-se o Granulito Uyarani, parcialmente recoberto por sedimentos quaternários e por um ignimbrito pliocênico. Neste trabalho, o Granulito Uyarani é caracterizado como granulito félsico que apresenta enclaves máficos de granulito máfico, que tiveram como protólitos, respectivamente, sienogranitos, granodioritos e quartzo monzodioritos, enquanto o protólito do enclave tem composição gabroica. A análise estrutural demonstra seu caráter polideformado, com três fases de deformação $\left(\mathrm{F}_{1}, \mathrm{~F}_{2}\right.$ e $\left.\mathrm{F}_{3}\right)$ e tectônica rúptil marcada por fraturas e falhas na $\mathrm{F}_{3}$. A fase $\mathrm{F}_{1}$ é ligada ao metamorfismo $\mathrm{M}_{1}$, que alcançou condições de fácies granulito para o Granulito Uyarani, já na fase $\mathrm{F}_{2}$ ocorre $\mathrm{o} \mathrm{M}_{2}$, responsável por um retrometamorfismo para fácies xisto verde. A litoquímica do granulito félsico revela que o protólito foi gerado por magmatismo cálcio-alcalino, metaluminoso a peraluminoso, magnesiano; já os enclaves de granulito máfico mostram a existência de um magma básico associado, em ambiente de arco magmático com ocorrência de mistura de magmas. As idades de cristalização do granulito félsico de $1.859 \pm 200 \mathrm{Ma}$ e $2.020 \pm 130 \mathrm{Ma}$, disponíveis na literatura, obtidas, respectivamente, pelos métodos $\mathrm{Rb} / \mathrm{Sr}$, em rocha total e U/Pb (TIMS) em zircão, são contraditórias e têm erros elevados. A análise geocronológica realizada neste trabalho revelou uma idade de cristalização, U/Pb (SHRIMP) em zircão, de 1.736 $\pm 5.1 \mathrm{Ma}$ para o granulito félsico. A idade de $1.157 \pm 60 \mathrm{Ma}$, admitida até então como pico metamórfico, considerando o intercepto inferior do diagrama concórdia da análise U/Pb em zircão, também é contestável. Portanto, consideram-se, neste trabalho, as idades estabelecidas a partir dos métodos $\mathrm{Ar} / \mathrm{Ar}$ em hornblenda com um platô de $982 \pm 2 \mathrm{Ma}$ e $\mathrm{Sm} / \mathrm{Nd}$, em isócrona mineral, de $1.008 \pm 16 \mathrm{Ma}$, que indicam a atuação de um episódio termal regional, associado à evolução da Orogenia Grenvilliana-Sunsás, também nas rochas granulíticas estudadas, sugerindo sua conexão com as faixas móveis da Província Geocronológica Sunsás do SW do Cráton Amazônico.
\end{abstract}

Palavras-chave: Granulito Uyarani; Embasamento Pré-Andino; Metamorfismo de Alto Grau; Orogenia Grenvilliana-Sunsás.

\begin{abstract}
The pre-Andean basement consists of thirteen major paleoproterozoic terranes as well as the Arequipa-Antofalla Terrane, and among its outcrops occurs the Uyarani Granulite partially covered by Quaternary sediments, and a Pliocene ignimbrite. The Uyarani Granulite is characterized in this paper as a Felsic Granulite who presenting mafic enclaves of Mafic Granulite which had the protolith, respectively, syenogranites, granodiorites and quartz monzodiorites while the protolith of enclave has grabroic composition. The structural analysis reveals the polydeformed character of these rocks which have undergone three phases of deformation $\mathrm{F}_{1}, \mathrm{~F}_{2}$ and $\mathrm{F}_{3}$ and a brittle event marked by $\mathrm{F}_{3}$ fractures and faults. The $\mathrm{F}_{1}$ stage is related to the $M_{1}$ granulite facies metamorphism acting on the Uyarani Granulite, while the $F_{2}$ phase is marked by $M_{2}$, a greenschist facies retro-metamorphism. Lithochemistry reveals the felsic granulite has a calcium-alkaline signature, varying from metaluminous to peraluminous, magnesian magmatism. However, the enclaves reveal the existence of an associated basic magma, in
\end{abstract}


magmatic arc setting with mixture of magmas. The crystallization age of felsic granulite, $1859 \pm 200 \mathrm{Ma}$ and $2020 \pm 130 \mathrm{Ma}$, available in the literature, obtained respectively, by the $\mathrm{Rb} / \mathrm{Sr}$ methods whole rock and U/Pb (TIMS) zircon, are contradictory and have high errors. The geochronological current analysis revealed a crystallization age, U/Pb (SHRIMP) zircon, of $1736 \pm 5.1 \mathrm{Ma}$ for the felsic granulite. The age of $1157 \pm 60 \mathrm{Ma}$ admitted until then as metamorphic peak, considering the lower intercept analysis concord diagram $\mathrm{U} / \mathrm{Pb}$ zircon, it is also questionable. So, are considered in this work, the ages established by the methods Ar/Ar hornblende plateau age of $982 \pm 2 \mathrm{Ma}$ and $\mathrm{Sm} / \mathrm{Nd}$ mineral isochron of $1008 \pm 16 \mathrm{Ma}$, indicating the role of a regional thermal episode, coupled with the evolution of Grenvilliana-Sunsás Orogeny, also in granulite rocks studied, suggesting its connection with the moving tracks of Sunsás geochronological province at the SW of Amazon Craton.

Keywords: Uyarani Granulite; Pre-Andean Basement; High-grade Metamorphism; Grenvillian-Sunsas Orogeny.

\section{INTRODUÇÃO}

O embasamento pré-andino foi inicialmente considerado como uma aglomeração de terrenos autóctones, ou seja, parte integrante da margem oeste do atual continente sul-americano desde a configuração do Supercontinente Rodínia (James, 1971; Cobbing et al., 1977; Dalmayrac et al., 1977). Porém, segundo Coira et al. (1982), Monger et al. (1982), Dalziel e Forsythe (1985), Ramos (1986), Loewy et al. (2004), Rapela et al. (2007), esse embasamento é formado por diversos terrenos suspeitos acrescidos à margem do Cráton Amazônico.

O terreno Arequipa-Antofalla registra idades paleoproterozoicas (Dalmayrac et al., 1977; Cobbing et al., 1977; Wörner et al., 2000; Loewy et al., 2004); e, de acordo com Ramos (2008), teria uma relação direta com a formação do arco magmático Sunsás, por ter atuado como um terreno intermediário entre os crátons Amazônico e Laurentia durante o mesoproterozoico.

O Granulito Uyarani é constituído por rochas granulíticas félsicas com enclaves de granulito máfico, parcialmente recobertos por sedimentos quaternários e ignimbritos pliocênicos. Essa unidade foi exposta por um alçamento do embasamento, situa-se nos limites do terreno Antofalla e registra a história geológica pré-cambriana do embasamento andino.

Os dados geocronológicos apresentados por Wörner et al. (2000) de U/Pb (TIMS) em grãos de zircão indicam cristalização em torno de $2.020 \pm 130 \mathrm{Ma}$ e resfriamento regional em $1.157 \pm 60 \mathrm{Ma}$.

Os dados existentes não definem claramente a constituição litológica e a evolução estrutural e petrológica dos Granulitos Uyarani. Mesmo os resultados geocronológicos apresentados por Wörner et al. (2000) não definem com precisão a idade de formação dessas rochas.

O objetivo deste trabalho foi contribuir para o entendimento da evolução geológica e tectônica de parte do embasamento pré-cambriano do Altiplano Boliviano e discutir possíveis correlações entre o terreno Antofalla e o Cráton Amazônico. Com esse propósito, o Granulito Uyarani foi investigado com relação a sua petrogênese, sua história deformacional e metamórfica e sua idade de formação, definida pelo método $\mathrm{U} / \mathrm{Pb}$ (SHRIMP) em zircão.

\section{CONTEXTO GEOLÓGICO REGIONAL}

A margem continental andina é dividida em Andes Superior, Central e Inferior (Mpodozis e Ramos, 1990); na configuração dos Andes Central estão inseridos os terrenos ArequipaAntofalla, Marañon, Mejillonia, Chilenia, Cuyania, Famatina e Patagônia (Dalziel e Forsythe, 1985; Ramos, 1988, 2008, 2010; Figura 1).

Dalziel (1997), Cordani et al. (2000), Jaillard et al. (2000), Brito Neves (2003) e Fuck et al. (2008) sugerem que o lado oeste do Cráton Amazônico tenha se chocado com Laurentia, gerando o arco magmático Sunsás, porém o arco magmático localiza-se muito distante da possível sutura.

Posteriormente, Loewy et al. (2004) propõem que o terreno Arequipa-Antofalla seria intermediário aos crátons Amazônico e Laurentia, dando um maior sentido ao fato de o arco magmático estar longe da sutura.

Ramos (1988) e Bahlburg e Hervé (1997) propõem que os terrenos Arequipa e Antofalla eram dois terrenos distintos que, após o primeiro choque, passaram a se comportar como um só. Segundo Ramos (2008), o terreno Antofalla chocou-se com o Cráton Amazônico em três momentos distintos, inicialmente durante a formação do Rodínia, na Orogenia Sunsás, em seguida constituindo o Gondwana pela Orogenia Brasiliana e, finalmente, na Orogenia Andina, compondo a estruturação atual do continente sul-americano.

O terreno Arequipa-Antofalla (AA) foi dividido por Loewy et al. (2004; Figura 2) em domínios norte, central e sul. O domínio norte é restrito ao terreno Arequipa; o domínio central do AA abrange os terrenos Arequipa e Antofalla, enquanto o domínio sul faz parte do terreno Antofalla.

O terreno Antofalla (Figura 3) estende-se da porção oeste de Puna, Argentina, até o litoral norte do Chile. Esse terreno compreende corpos graníticos e metamórficos orto e paraderivados de idade pré-cambriana a paleozoica (Lehmann, 1978; Tosdal, 1996; Wörner et al., 2000; Loewy et al., 2004) que registram a história geológica pré-andina, sendo eles: Cerro Uyarani, Belén, Quebrada Choja, Sierra Moreno, San Andrés, Berenguela, Saxamar, Cauchari, Cordón de Lila, Limón Verde e Antofalla.

O Cerro Uyarani, que se encontra no extremo norte do terreno Antofalla (Ramos, 1988), foi definido inicialmente pelo Serviço Geológico da Bolívia como um representante 


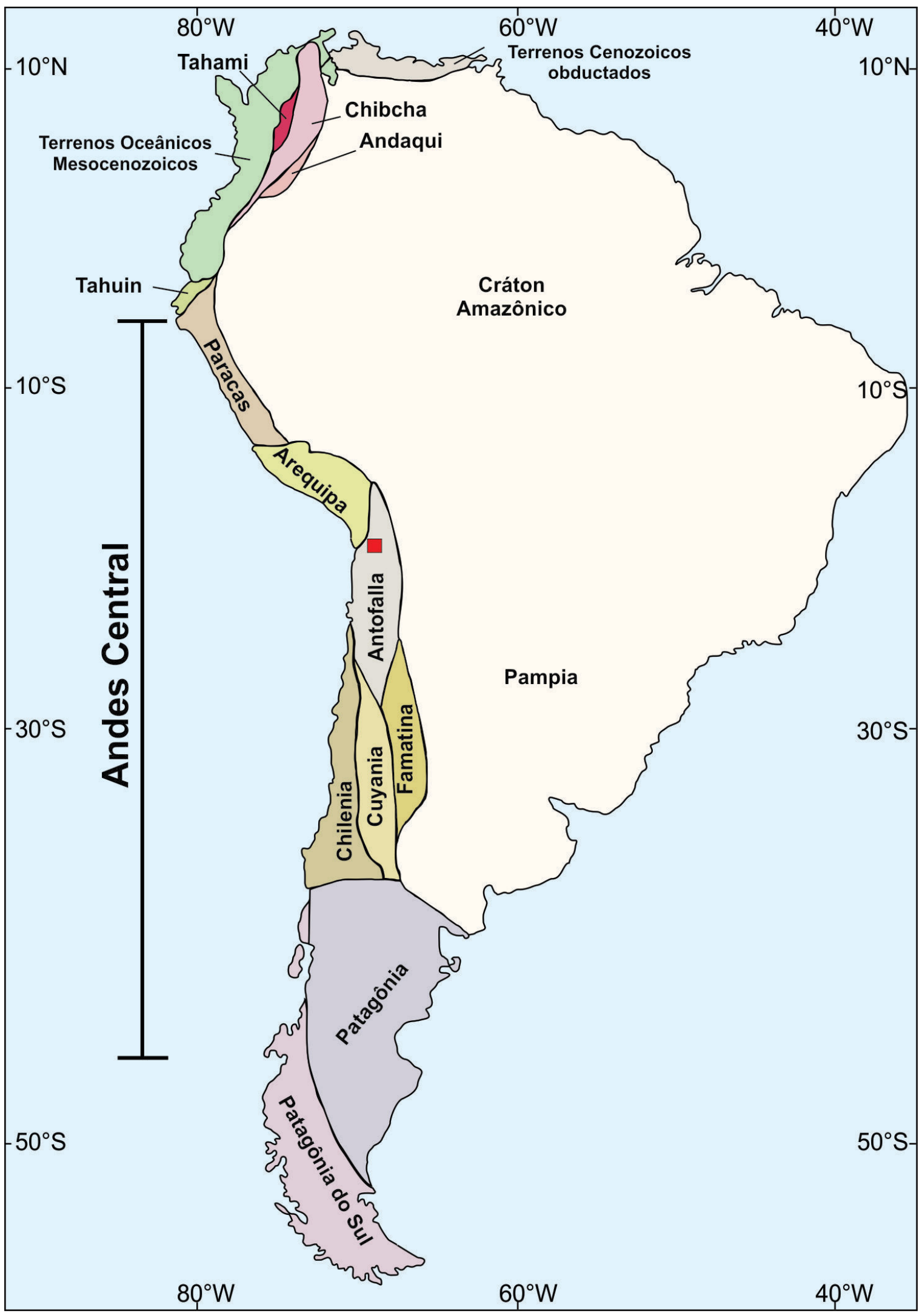

Figura 1. (A) Mapa da América do Sul com principais terrenos do embasamento pré-andino, extraído de Ramos (2010); a quadrícula em vermelho corresponde à região pesquisada. 
metamórfico do embasamento pré-andino em meio à cadeia de montanhas andinas. As rochas do cerro foram descritas inicialmente por Troeng et al. (1994) como gnaisse de composição granítica a granodiorítica, com a ocorrência de um ignimbrito ao norte e ao oeste do maciço, e obtiveram uma idade isocrônica $\mathrm{Rb} / \mathrm{Sr}$ em rocha total de $1.859 \pm 200 \mathrm{Ma}$.

Wörner et al. (2000) descrevem as rochas do Cerro Uyarani como granulito máfico, charnoquito e um fels

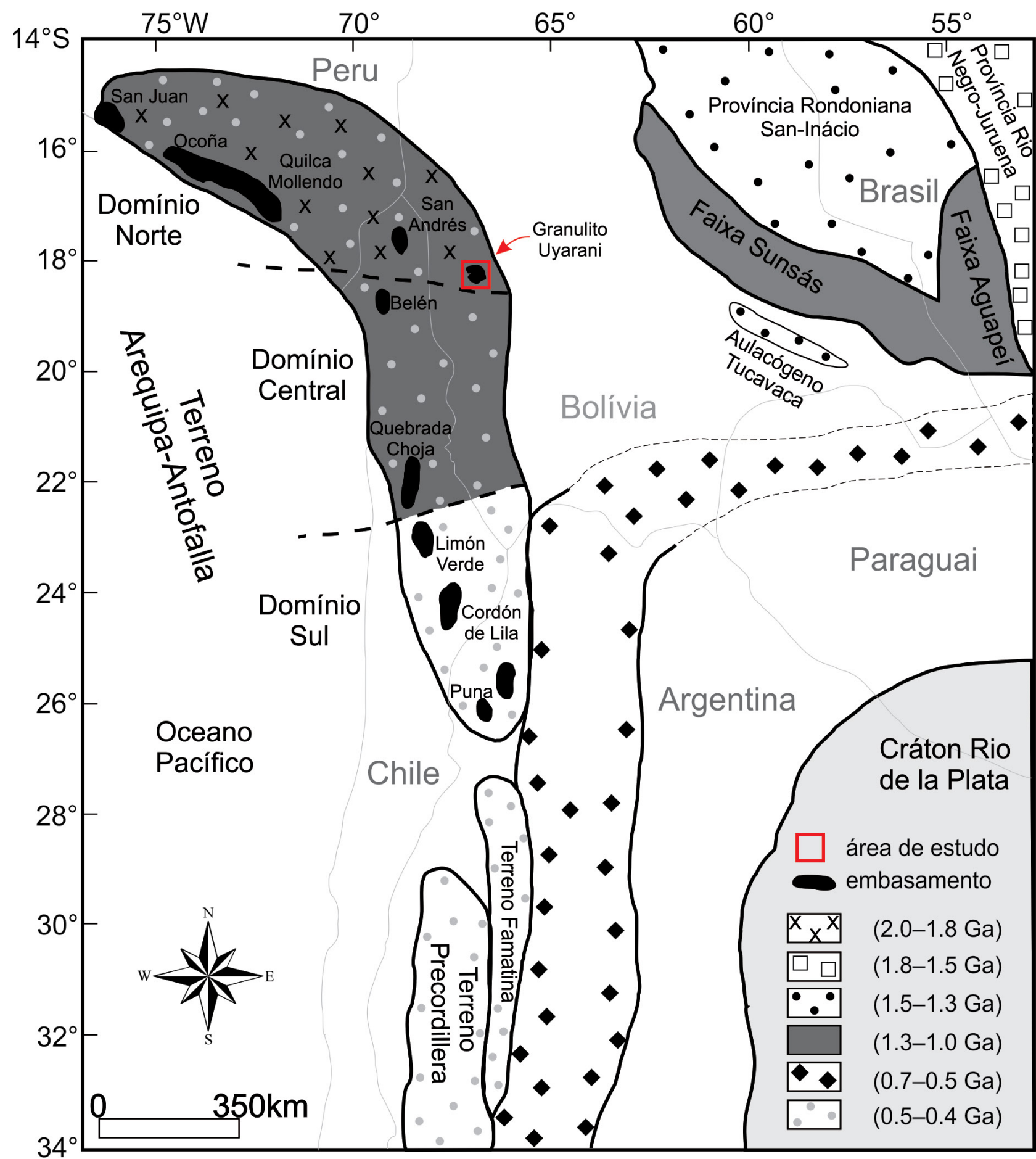

Figura 2. Mapa dos Terrenos Arequipa e Antofalla e das províncias ao seu redor evidenciando a divisão das unidades de embasamento dos terrenos Arequipa e Antofalla em domínios norte, central e sul. Modificado de Loewy et al. (2004). 
cálcio-silicatado, e apresentam resultado U/Pb (TIMS) em zircão, em que o intercepto superior foi interpretado como idade de cristalização, em $2.020 \pm 130 \mathrm{Ma}$, e o intercepto inferior como um evento metamórfico de $1.157 \pm 60 \mathrm{Ma}$. Apresentam idade plateau $\mathrm{Ar} / \mathrm{Ar}$ em hornblenda de $982 \pm$ $2 \mathrm{Ma}$ e diagrama isocrônico $\mathrm{Sm} / \mathrm{Nd}$ de $1.008 \pm 16 \mathrm{Ma}$. Esses autores apontam ainda que as rochas granulíticas mostram uma assinatura geoquímica típica de crosta heterogênea, com enriquecimento em litófilos de raios iônicos grandes (LILE), anomalia positiva de $\mathrm{Pb}$ e alta razão LREE/HREE.

Oliveira et al. (2015) descrevem o arcabouço polideformado dos granulitos do Cerro Uyarani e sugerem o registro de, pelo menos, dois eventos metamórficos, com evidências de retrogressão.

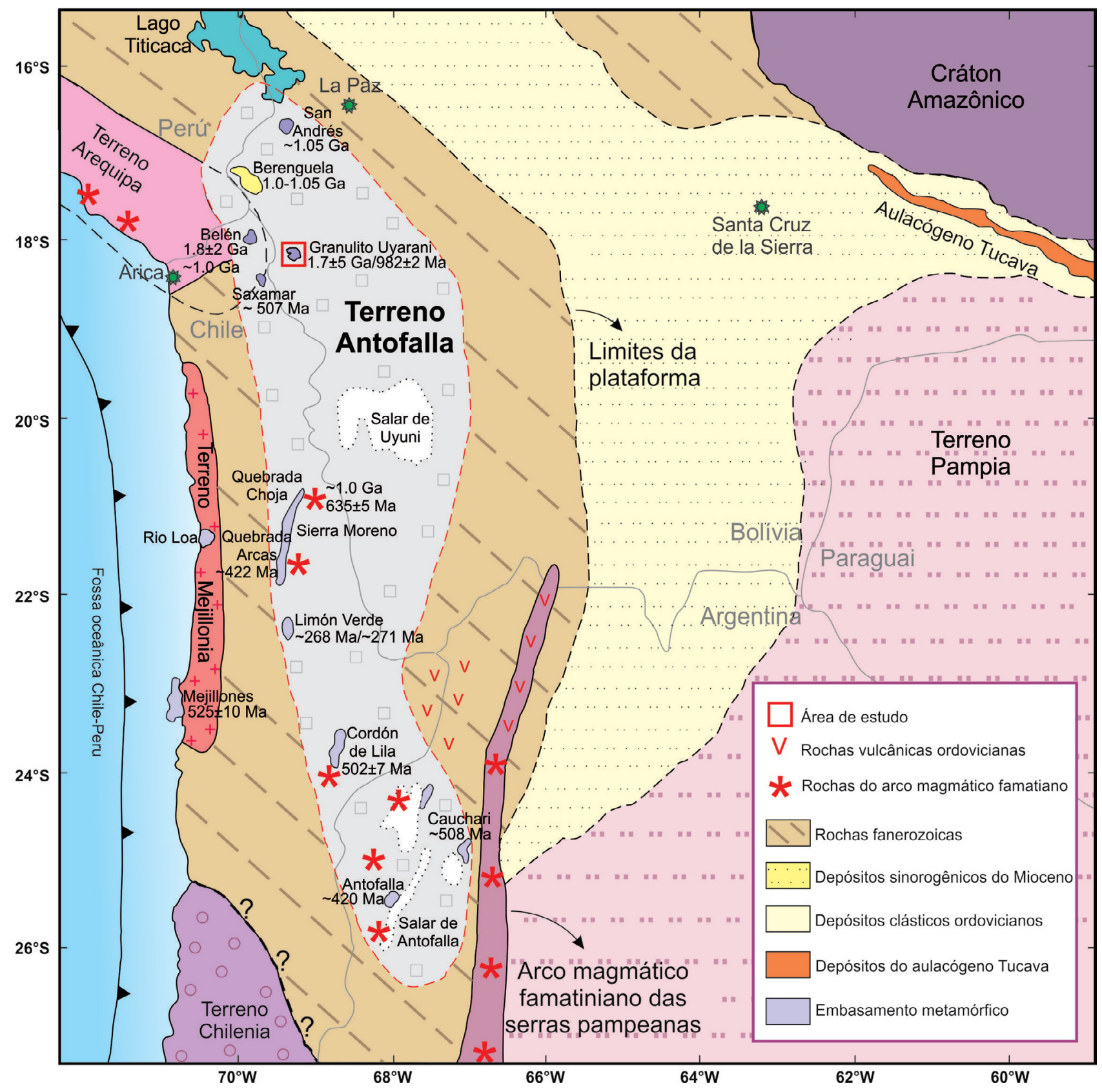

Figura 3. Limites inferidos do Terreno Antofalla e seus corpos graníticos e metamórficos representantes do embasamento. Modificado de Ramos (2008a). 


\section{GEOLOGIA E PETROGRAFIA}

O Granulito Uyarani, alvo deste estudo, constitui uma serra de aproximadamente $32 \mathrm{~km}^{2}$ situada na porção oeste do Altiplano da Bolívia, no departamento de Oruro, Província Sajama, município de Turco. Dista em torno de $45 \mathrm{~km}$ do Vulcão Sajama, $175 \mathrm{~km}$ do Salar de Uyuni e $290 \mathrm{~km}$ de Cochabamba.

Os estudos do Granulito Uyarani foram realizados por meio de interpretação inicial de imagem de satélite, seguida de mapeamento, em escala 1:25.000, com obtenção de dados geológicos e estruturais, bem como coleta de amostras para petrografia, geoquímica e geocronologia. Após a interpretação desses dados, foi possível a confecção do mapa geológico e estrutural do Granulito Uyarani (Figura 4) com a utilização do software ArcMap 10.2.1.

A confecção das lâminas delgadas foi realizada no Laboratório de Laminação da Universidade Federal de Mato Grosso (UFMT) e a petrografia microscópica foi feita a partir da descrição de 42 lâminas.

A unidade alvo deste trabalho é constituída por rochas granulíticas, parcialmente recobertas por litotipos vulcanoclásticos e por sedimentos inconsolidados quaternários eólicos e lacustres (Figura 5). Dois tipos de granulitos foram identificados, um félsico (dominante, com bandamento descontínuo) e outro máfico (como enclaves).

Os enclaves ocorrem centimétricos a métricos, apresentando-se dobrados com boudinage e morfologia variável entre alongados, arredondados e sigmoidais, sendo também observadas porções pegmatíticas.

Na porção N e NW da serra, encontram-se, cobrindo parcialmente o Granulito Uyarani, em contato discordante, rochas piroclásticas formadas por fluxo de púmice de cor cinza claro com diversos clastos de fragmentos de rocha, minerais e vidro, correspondendo a um ignimbrito pliocênico da Formação Pérez (Troeng et al., 1994). Observam-se ainda diques máficos de composição basáltica e granulação muito fina de larguras centimétricas a métricas e diques félsicos de granulação fina a pegmatítica, compostos por quartzo, feldspato alcalino e magnetita.

\section{Granulito félsico}

O granulito félsico apresenta granulação média e bandas félsicas e máficas de cores, respectivamente, cinza rosada e cinza. A primeira é formada principalmente por feldspato alcalino, plagioclásio e quartzo com níveis finos de piroxênio, anfibólio e biotita (Figura 6A); já a banda máfica constitui-se de intercalações de leitos formados por anfibólio e piroxênio e níveis subordinados quartzo-feldspático (Figura 6B).

Microscopicamente, o granulito félsico (Figura 7) apresenta texturas granoblástica e nematoblástica, expressas pela disposição orientada de, principalmente, grãos quartzofeldspáticos e cristais de piroxênio e anfibólio. A mineralogia principal é composta por feldspato alcalino pertítico, quartzo, plagioclásio (oligoclásio a andesina), por vezes mirmequítico, hiperstênio, diopsídio, hornblenda e biotita; enquanto os minerais de alteração e acessórios estão representados por biotita, granada, clorita, sericita e anfibólio da série actinolita-tremolita, calcita, argilominerais, óxido/hidróxidos de $\mathrm{Fe}$ (opacos), zircão e apatita.

\section{Granulito máfico (enclave)}

O granulito máfico é cinza escuro, de granulação variando desde fina até grossa, constituído por hornblenda, plagioclásio, piroxênio e raro quartzo (Figura 8).

O granulito máfico (Figura 9) apresenta textura predominantemente granonematoblástica constituída por orto e clinopiroxênio (hiperstênio e diopsídio), hornblenda, plagioclásio (andesina) e, raramente, grãos de quartzo, tendo como minerais de alteração clorita, sericita, talco, actinolita-tremolita e argilominerais; já os minerais acessórios são representados por apatita, zircão e opacos (Figura 10).

\section{ANÁLISE ESTRUTURAL E METAMORFISMO}

As observações em campo e os dados estruturais coletados possibilitaram a interpretação da história deformacional registrada pelas rochas do Granulito Uyarani. Para o tratamento dos dados estruturais foi empregado o software livre OpenStereo (Grohmann et al., 2011). Foram identificadas estruturas referentes aos comportamentos reológicos dúcteis e rúpteis; assim, a apresentação dos dados levou em conta a tectônica dúctil, mais antiga, e a rúptil, mais recente.

\section{Tectônica dúctil}

É dividida em três fases de deformação $\left(\mathrm{F}_{1}, \mathrm{~F}_{2}\right.$ e $\left.\mathrm{F}_{3}\right)$ para as rochas do Granulito Uyarani, descritas a seguir.

\section{Primeira fase de deformação $\left(F_{1}\right)$ e metamorfismo $\left(M_{\uparrow}\right)$}

A fase $\mathrm{F}_{1}$ é responsável pelo desenvolvimento da foliação penetrativa $S_{1}$, que incide como um bandamento gnáissico (Figura 11A) de atitude 192/27, mais comum na porção NW do Granulito Uyarani, e 360/10, principalmente na região central. Os enclaves máficos são foliados e achatados em concordância com a foliação $S_{1}$ (Figura 11B).

A fase de deformação $F_{1}$ é associada ao metamorfismo $M_{1}$, que possui uma paragênese de fácies granulito representada por hiperstênio, diopsídio, quartzo, andesina ou oligoclásio, biotita e hornblenda (Figuras 7 e 9). 


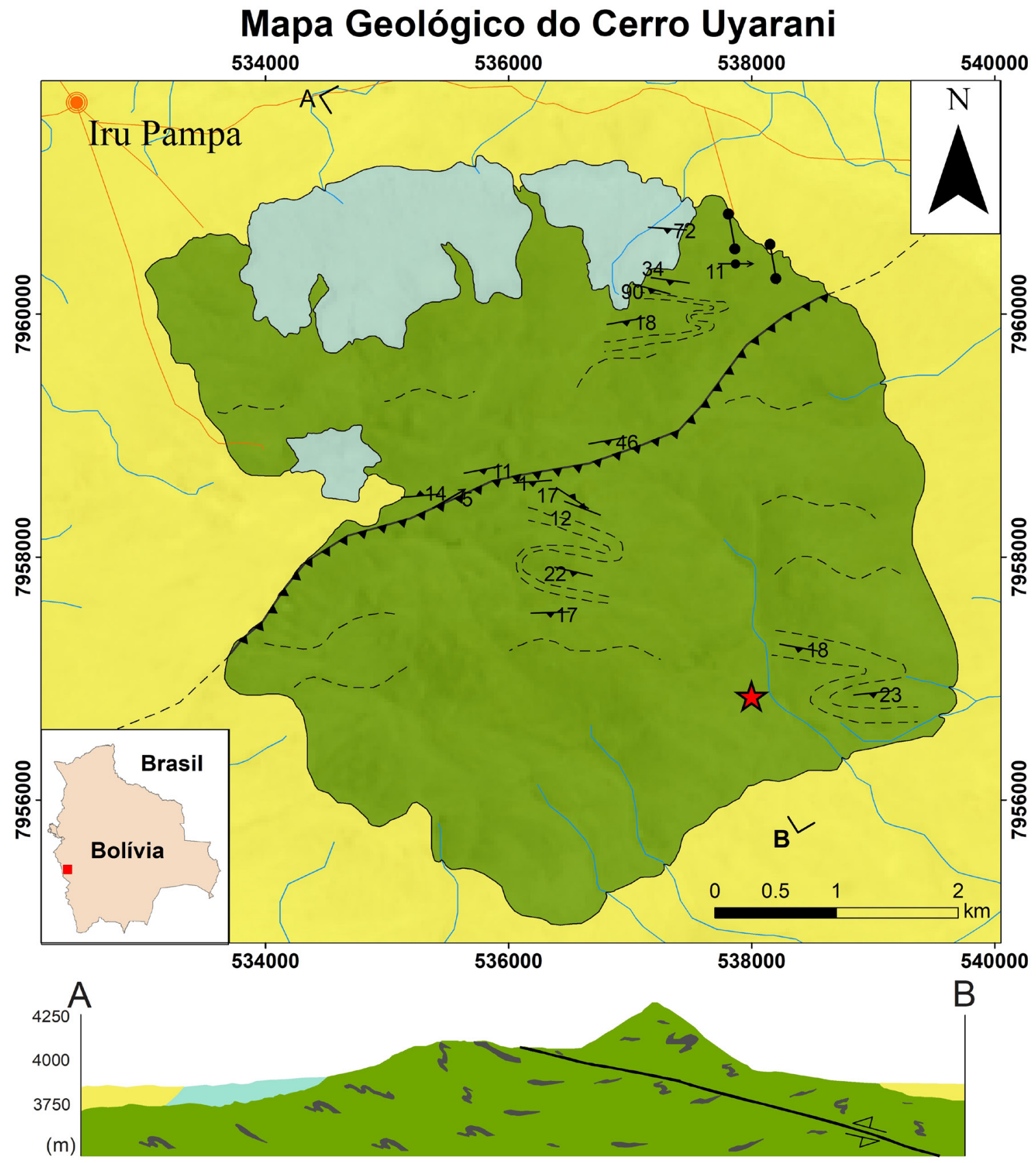

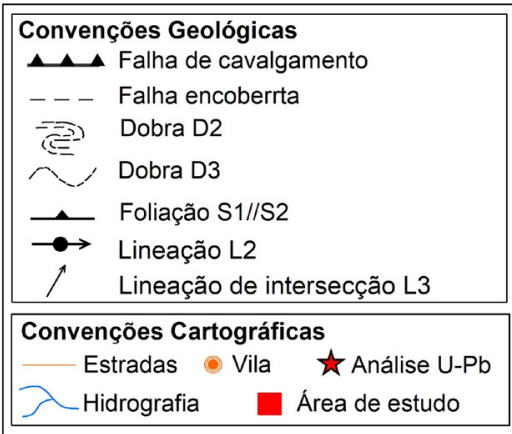

Quaternário

Sedimentos quaternários: sedimentos quaternários inconsolidados, depósitos aluvionares, fluviolacustres, fluvioglaciais, coluvionares, lacustres, morainas e dunas

\section{Neógeno}

Formação Perez: ignimbrito de fluxo piroclástico com enclaves de fragmentos de rocha, minerais e vidro

\section{Unidade Indivisa}

- Diques máficos: diques de diabásio de granulação fina

\section{Estareriano}

Granulito Uyarani: granulito félsico com enclaves de granulito máfico

Figura 4. Mapa geológico do Granulito Uyarani, com perfil esquemático AB mostrando as principais estruturas existentes e localização do ponto de amostragem da análise geocronológica. 


\section{Segunda fase de deformação $\left(F_{2}\right)$ e metamorfismo $\left(M_{2}\right)$}

A fase de deformação $F_{2}$ (Figura 12) é caracterizada por dobras recumbentes $\mathrm{D}_{2}$, desenhadas pelas superfícies do bandamento $S_{1}$, o eixo da $D_{2}$ tem atitude $270 / 25$ e o plano axial mede 184/10. A $\mathrm{S}_{2}$ gera uma xistosidade de $184 / 10$ (Figura 12A) a partir da transposição da $S_{1}$ nas charneiras das dobras $\mathrm{D}_{2}$, portanto nos flancos das dobras $\mathrm{D}_{2}$ ocorre
$\mathrm{S}_{1} / / \mathrm{S}_{2}$, porém nas charneiras essas foliações são ortogonais. A orientação de minerais máficos contidos nos planos da xistosidade $\mathrm{S}_{2}$ evidencia a lineação $\mathrm{L}_{2}$, de atitude 90/11.

Está relacionado à fase de deformação $\mathrm{F}_{2} \mathrm{o}$ metamorfismo $M_{2}$, com uma paragênese mineral que registra um retrometamorfismo evidenciado por presença de clorita, actinolita-tremolita, biotita e sericita (Figura 10).

É comum a formação de dobras sem raiz, dobras similares e indicadores cinemáticos em escalas macro e microscópica,
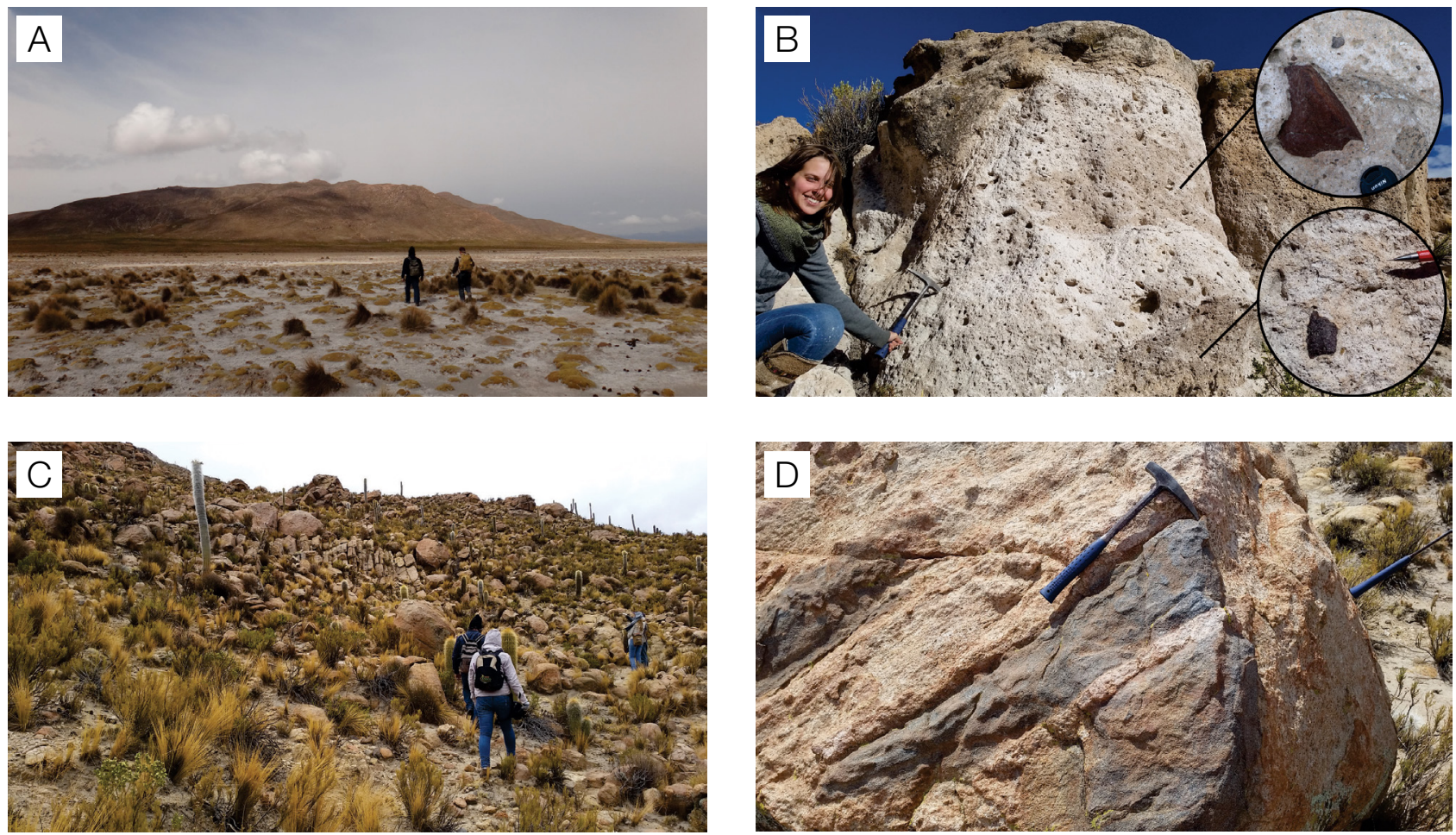

Figura 5. Fotos do Granulito Uyarani. (A) Vista da serra; (B) ignimbrito com fragmentos de rocha; (C) foto mostrando a abrangência dos afloramentos de granulito félsico; (D) enclaves de granulito máfico no granulito félsico e dique pegmatítico félsico cortando os granulitos.
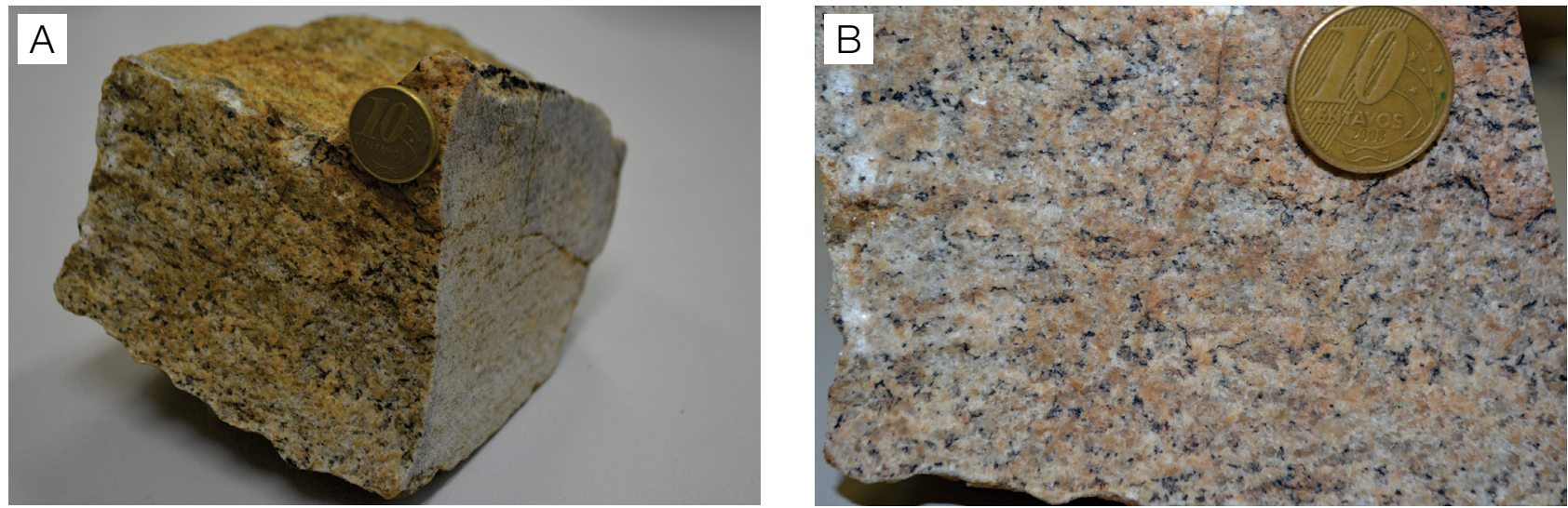

Figura 6. Amostras do granulito félsico. (A) Bandamento composicional; (B) detalhe das intercalações de níveis claros e escuros. 

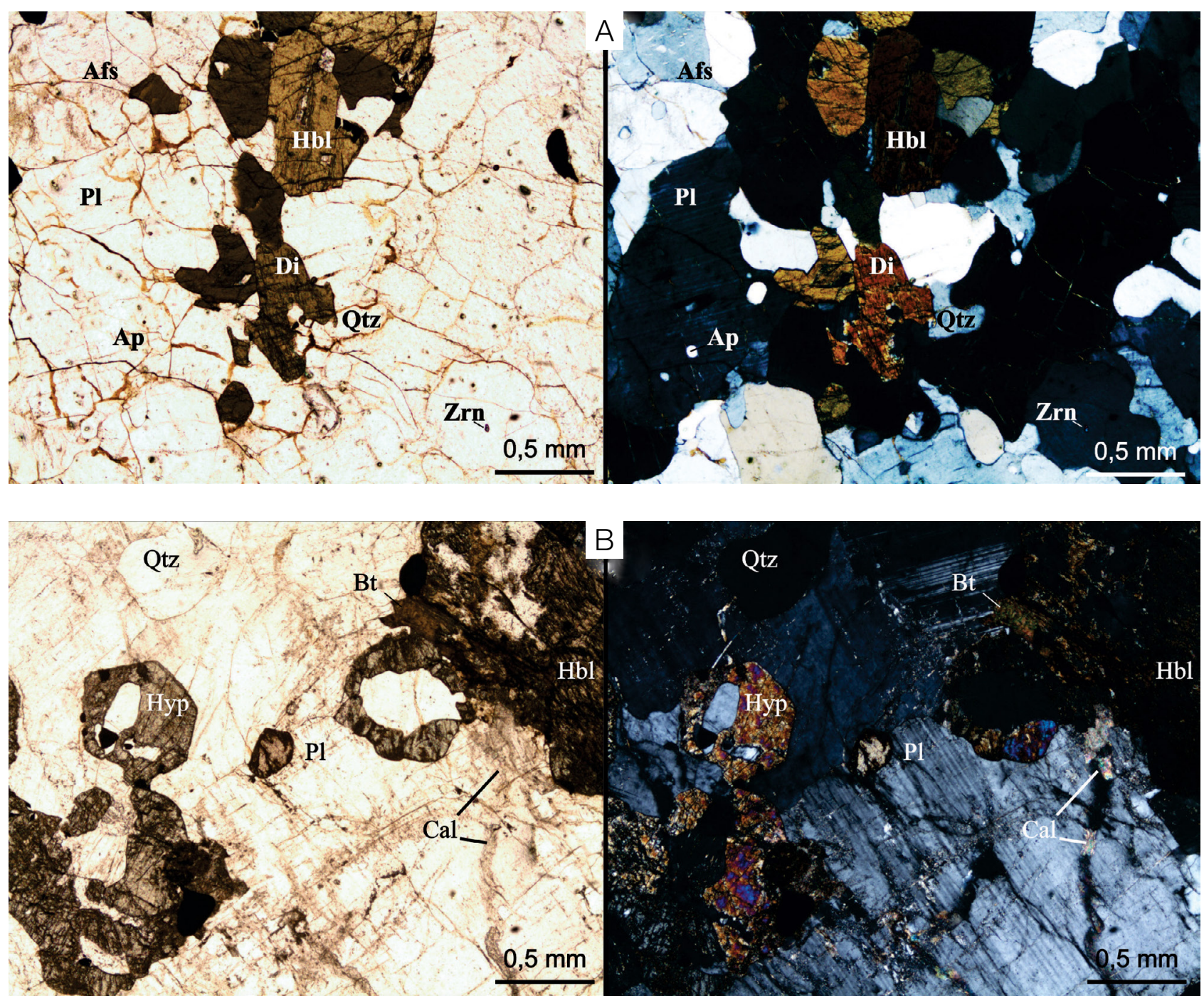

Figura 7. Fotomicrografias do granulito félsico, polarizadores paralelos à esquerda e cruzados à direita. (A) microclina, plagioclásio, hornblenda e diopsídio gerando textura granoblástica; (B) hiperstênio envolvendo quartzo e associação de hornblenda e biotita, saussuritização do plagioclásio e calcita formando vênulas.
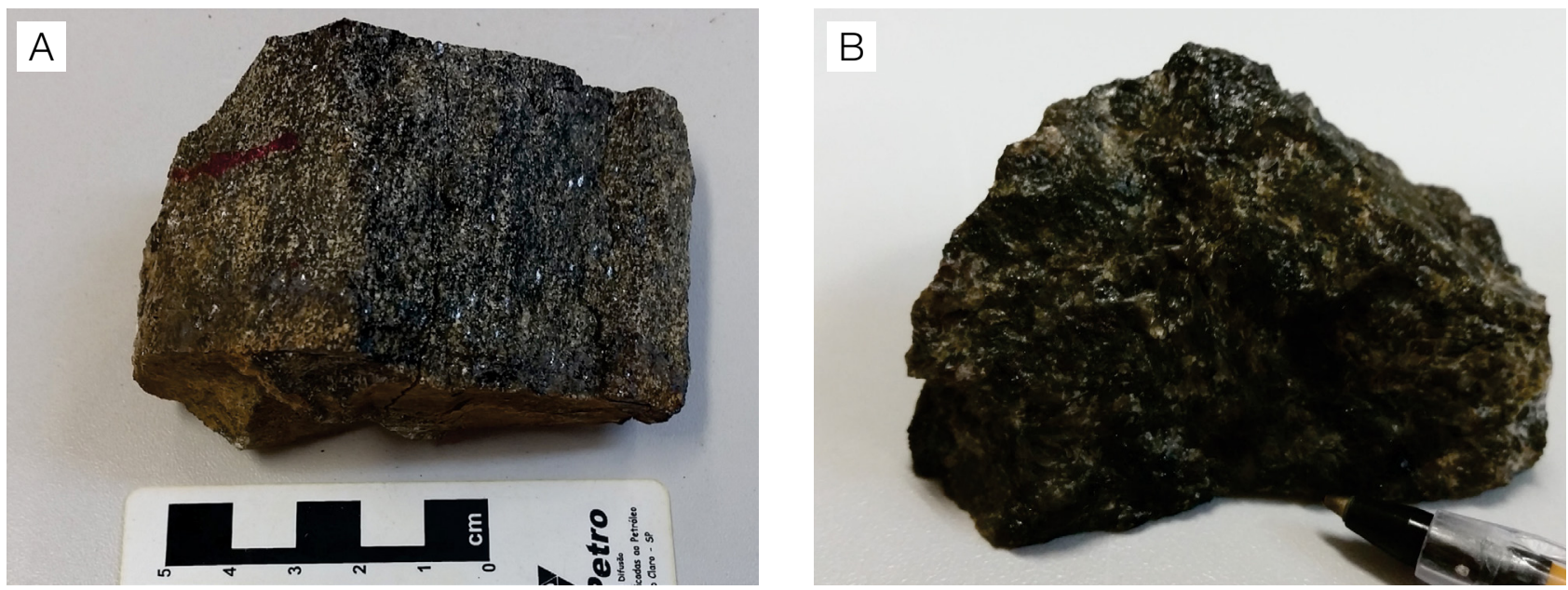

Figura 8. Amostras do granulito máfico de cor cinza escuro composto por anfibólio, piroxênio, plagioclásio e raro quartzo. (A) Bandamento milimétrico e granulação fina; (B) granulação grossa. 


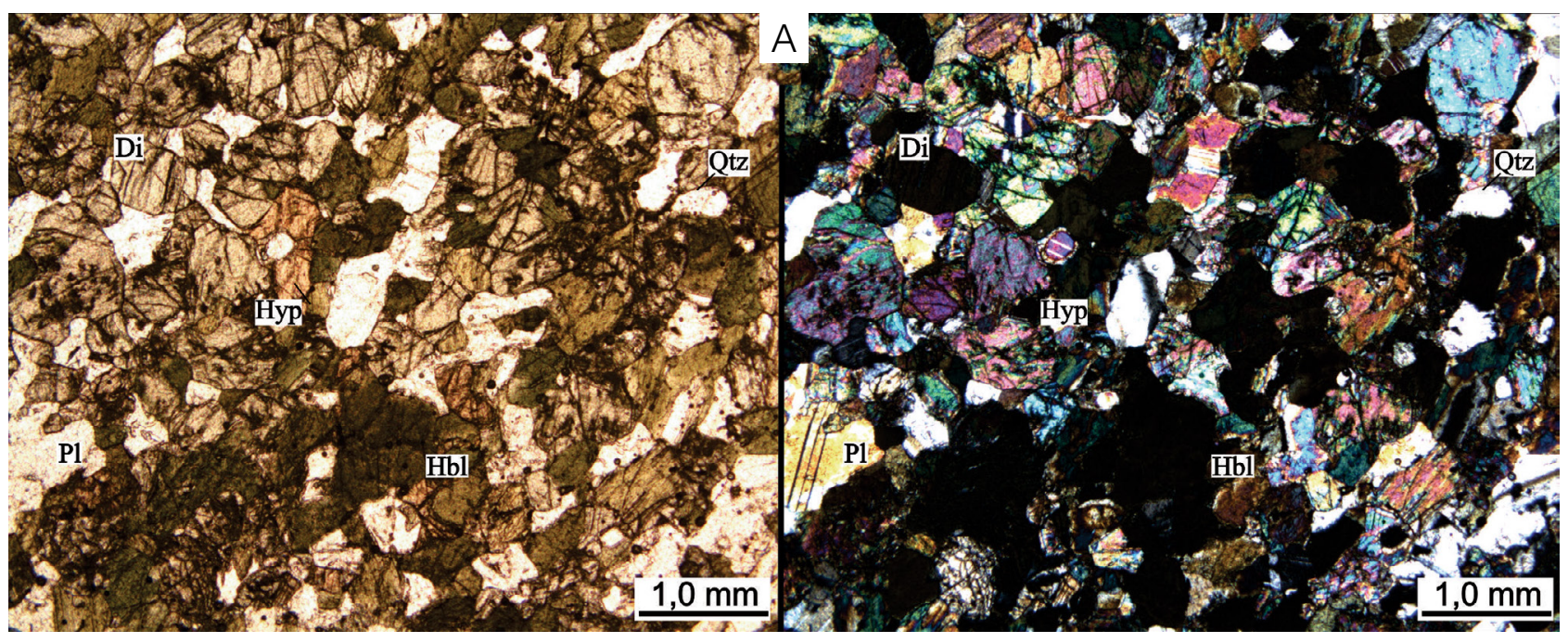

Figura 9. Fotomicrografias do granulito máfico ilustrando textura granonematoblástica formada por grande percentual de piroxênio (hiperstênio) e hornblenda e raros cristais de plagioclásio (andesina) e quartzo. Polarizadores paralelos à esquerda e cruzados à direita.
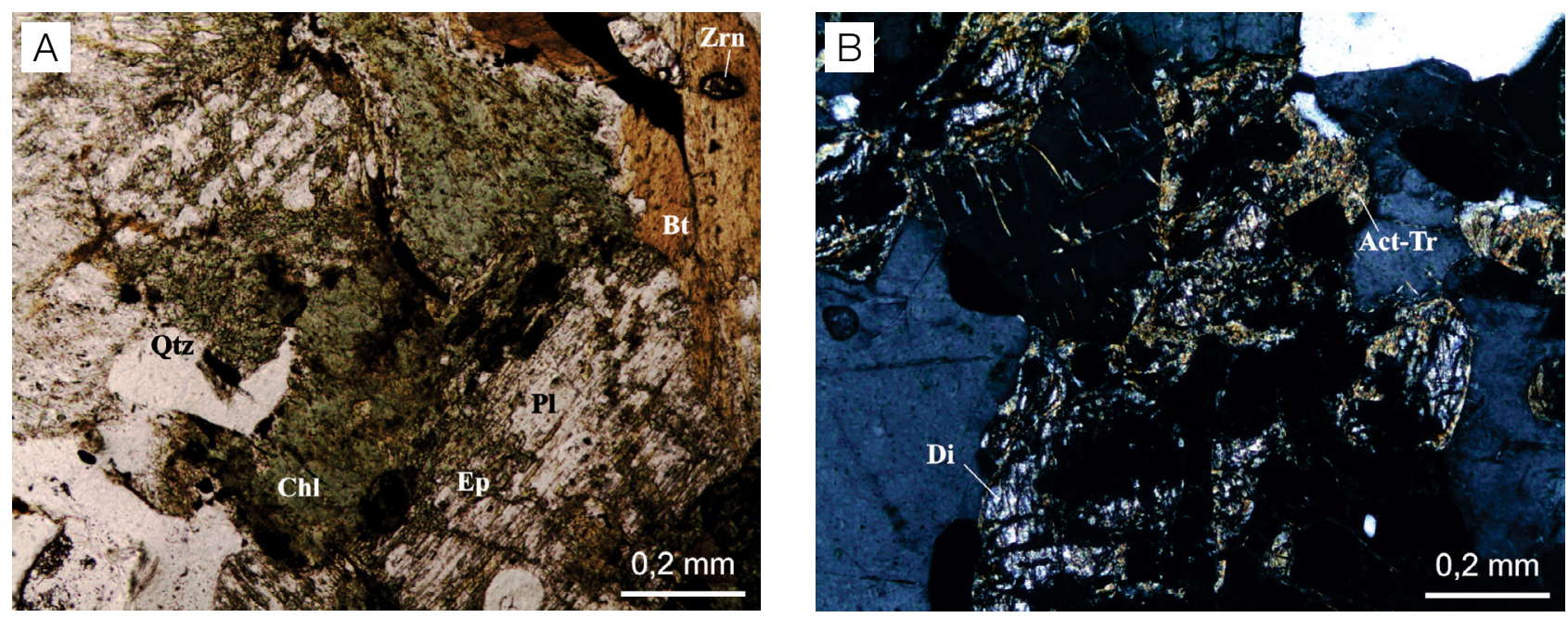

Figura 10. Fotomicrografias evidenciando o retrometamorfismo dos granulitos. (A) Agregado de clorita, biotita e epídoto; (B) diopsídio parcialmente substituído por actinolita-tremolita. Polarizadores paralelos em A e cruzados em B.
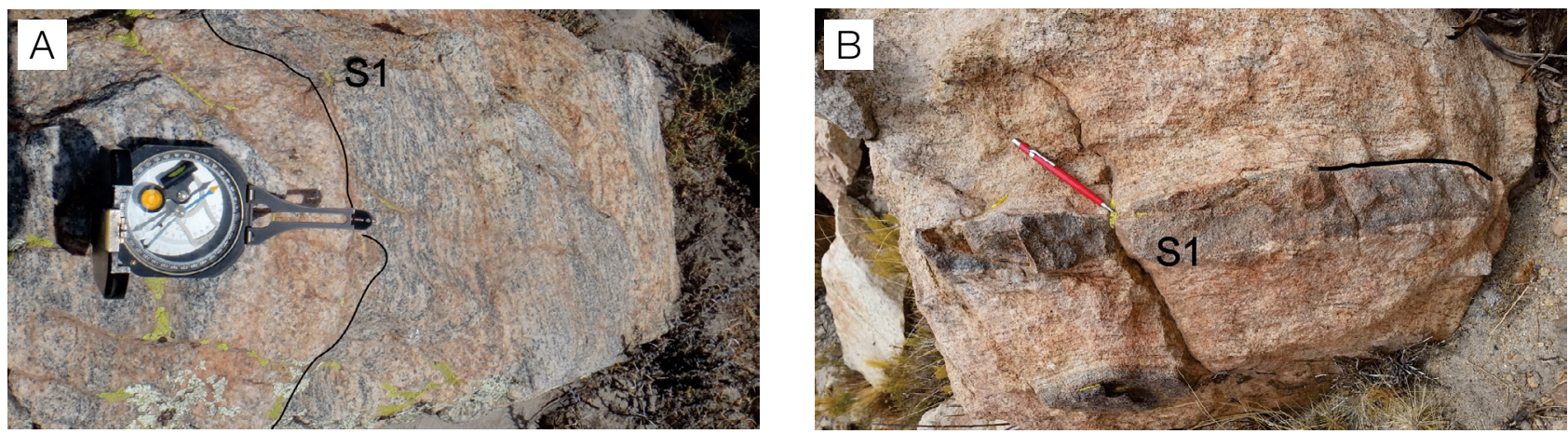

Figura 11. Estruturas geradas na fase de deformação $F_{1}$. (A) Granulito félsico, evidenciando a separação entre bandas félsicas e máficas e a xistosidade na banda máfica; $(B)$ contato entre granulito félsico e enclave de granulito máfico obedecendo à orientação da foliação $S_{1}$, é possível notar a xistosidade na banda félsica do granulito félsico. 
como enclaves rotacionados, foliação SC e sigmoides que registram um movimento tangencial de baixo ângulo (cavalgamento), com transporte de topo para NW, ao longo de discretas zonas de cisalhamento reverso $\mathrm{Zc}_{2}$ (Figura 13).

\section{Terceira fase de deformação $\left(F_{3}\right)$}

A fase deformacional $\mathrm{F}_{3}$ é marcada por dobras $\mathrm{D}_{3}$ (Figuras 14A e 15) de dimensões centimétricas a quilométricas, desenhadas a partir das foliações $\mathrm{S}_{1}$ e $\mathrm{S}_{2}$, que são abertas, simétricas e suaves, seus flancos têm atitudes $192 / 27$ e $360 / 10$, e seu plano axial mede 22/89. Exibe uma lineação de intersecção $\mathrm{L}_{3}$ (Figuras 14B e 15) de atitude 60/05.

\section{Tectônica rúptil}

As falhas e fraturas que afetam as rochas do Cerro Uyarani são coincidentes com a terceira fase de deformação.
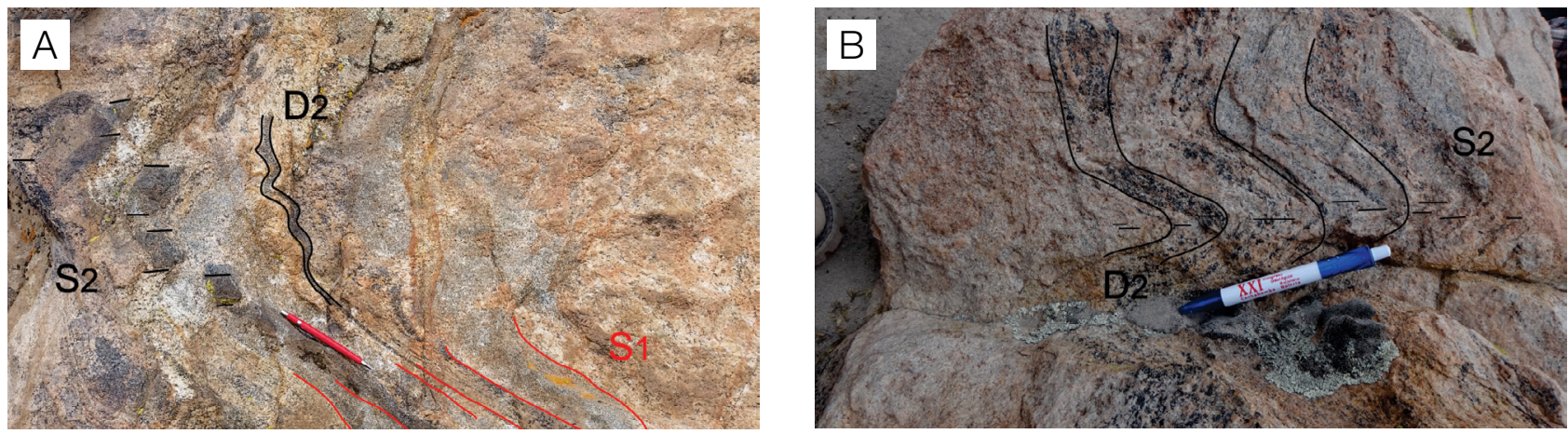

Figura 12. Estruturas geradas na fase de deformação $F_{2}$. (A) Granulito félsico e enclaves de granulito máfico dobrados pela $D_{2}$, nota-se a transposição da foliação $S_{1}$ nas charneiras dos enclaves dobrados; $(B)$ dobras $D_{2}$ desenhadas pela superfície do bandamento do granulito félsico.
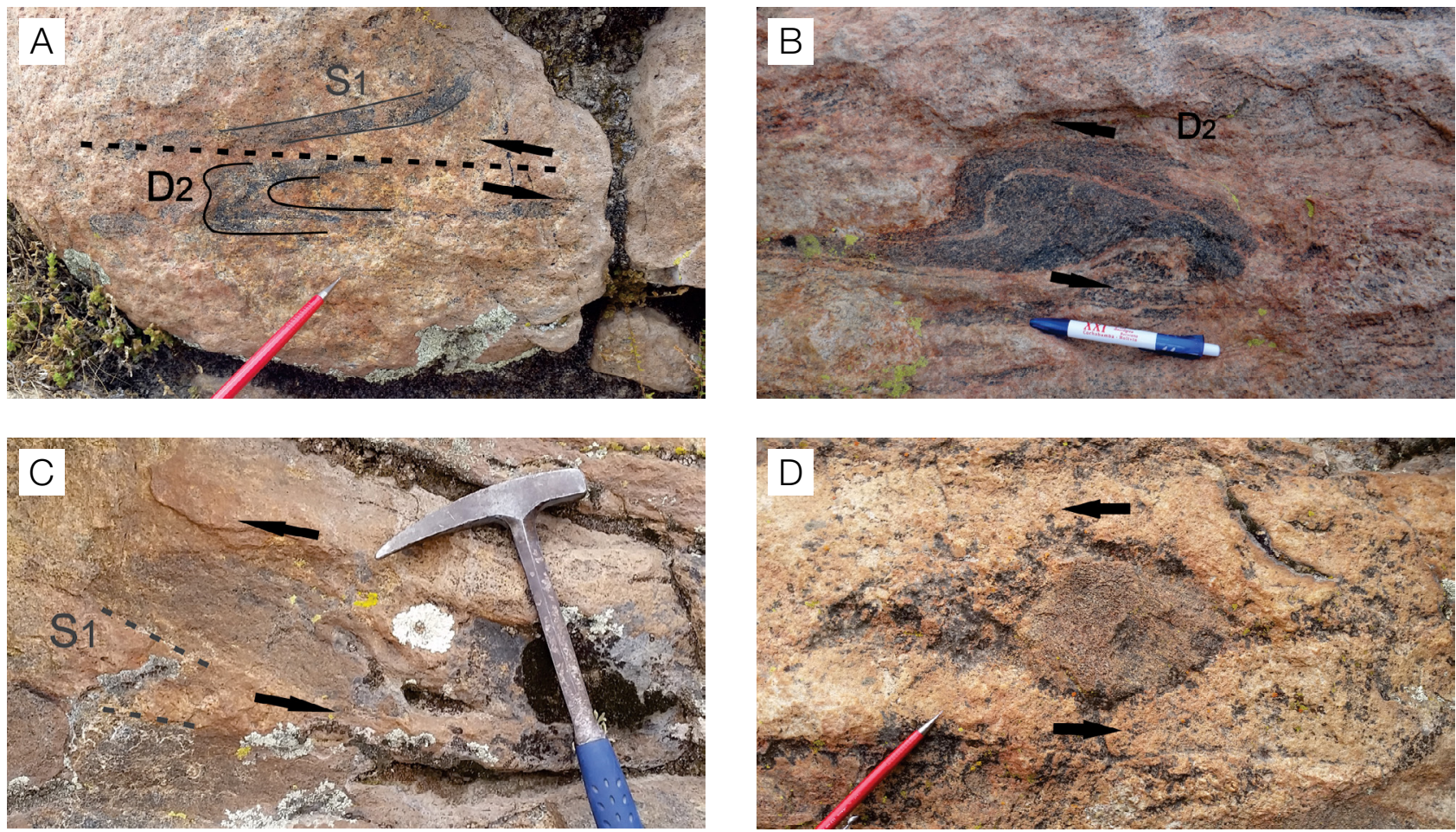

Figura 13. Dobras e indicadores cinemáticos atribuídos à fase $F_{2}$ evidenciando movimentos de cavalgamento. (A) Dobra $D_{2}$ sem raiz ou dobra com estrutura em cabo de guarda-chuva; (B) cavalgamento de um flanco da dobra $D_{2}$ desenvolvendo um reverse drag fold; (C) enclave sigmoidal de granulito máfico, oblíquo em relação à xistosidade e ao bandamento; (D) enclave rotacionado com sombra de pressão. 
As fraturas foram definidas como clivagem disjuntiva $\mathrm{J}_{1}$ e $\mathrm{J}_{2}$ (Figura 16). A $\mathrm{J}_{1}$ comporta-se como fraturas paralelas ao plano axial das dobras $\mathrm{D}_{3}$, com uma direção de máxima modal N70E e mergulhos altos, variando entre $65^{\circ}$ e $90^{\circ}$ para NW. A $\mathrm{J}_{2}$ é perpendicular ao plano axial da dobra $\mathrm{D}_{3}$, apresenta direção N34E e mergulhos altos variando entre $70^{\circ}$ e $90^{\circ}$ para NW. O sistema de falhas normais tem atitude N55E/85SE e desloca o bandamento $\mathrm{S}_{1}$ (Figura 17); também foi possível observar em imagem de satélite um sistema de falhas NW.
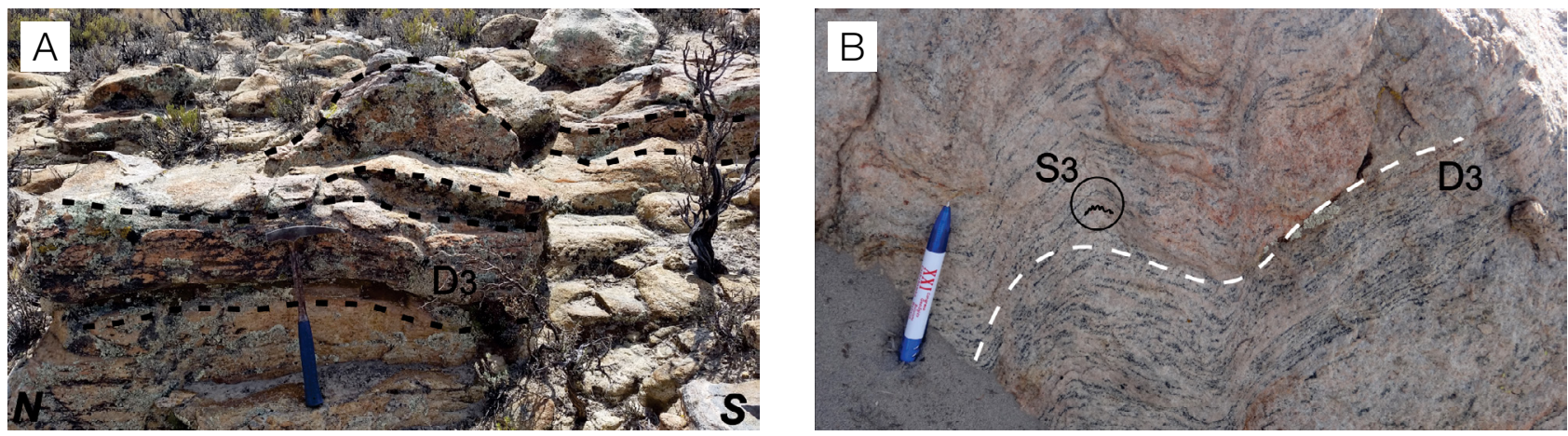

Figura 14. Estruturas geradas na fase de deformação $F_{3}$. (A) Dobras $D_{3}$ suaves, abertas e simétricas, desenhadas no bandamento e a xistosidade preexistente; (B) detalhe para a clivagem de crenulação $S_{3}$.
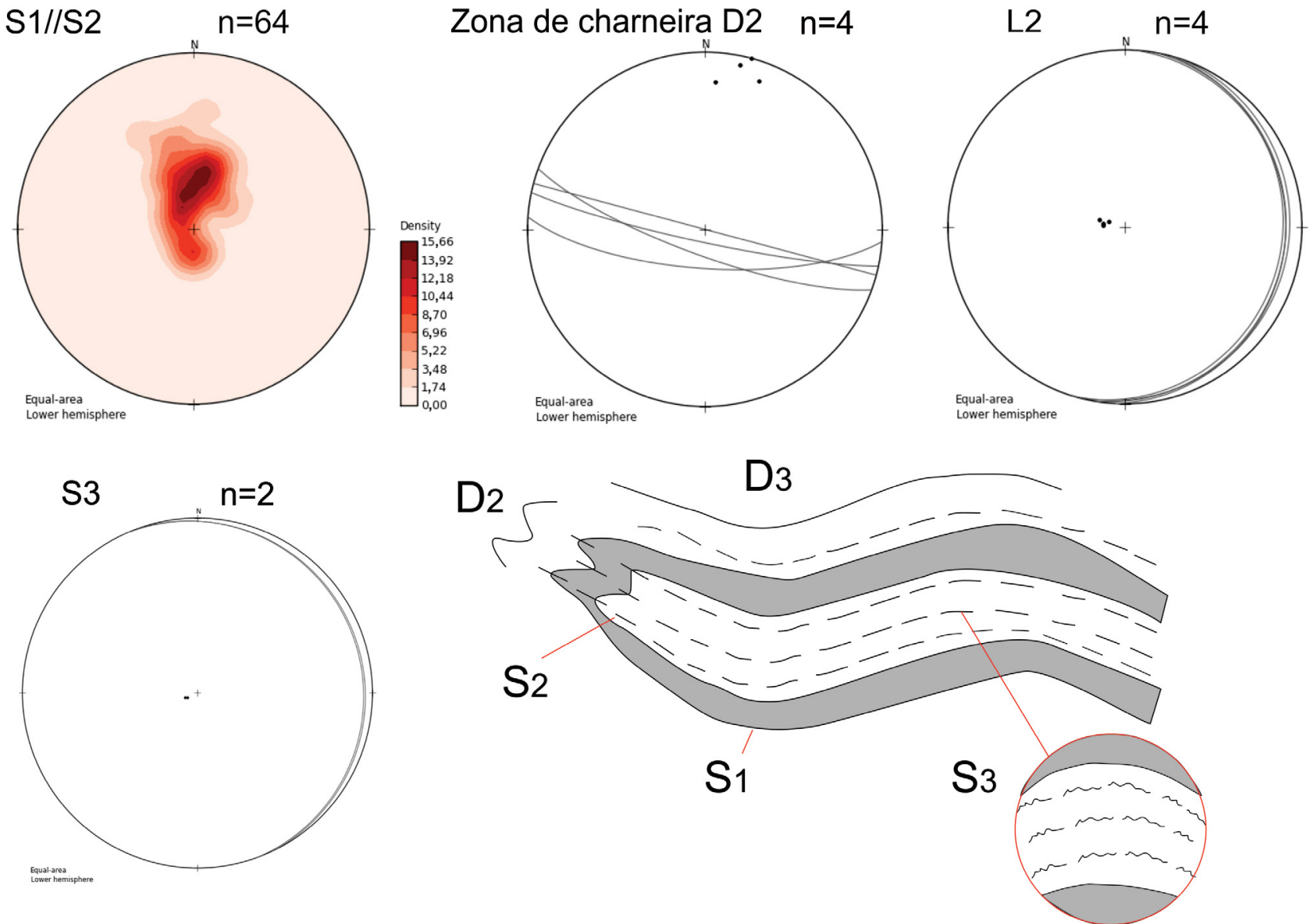

Figura 15. Diagramas de isofrequência para as foliações $S_{1}, S_{2}, S_{3}$ e lineação $L_{2}$. Desenho esquemático mostrando a sobreposição das fases deformacionais. 


\section{LITOQUÍMICA DO GRANULITO UYARANI}

A escolha das amostras para análise geoquímica foi precedida de caracterização petrográfica, em escalas macro e microscópica, o que permitiu a separação em granulito félsico e granulito máfico. As 12 amostras foram preparadas nos laboratórios da Faculdade de Geociências (UFMT), sendo 8 amostras do granulito félsico e 4 do granulito máfico. As análises químicas (Tabela 1) foram realizadas no Laboratório de Minerais Bureau Veritas, em Vancouver, Canadá, para elementos maiores $\left(\mathrm{SiO}_{2}\right.$, $\mathrm{Al}_{2} \mathrm{O}_{3}, \mathrm{Fe}_{2} \mathrm{O}_{3}, \mathrm{MgO}, \mathrm{CaO}, \mathrm{Na}_{2} \mathrm{O}, \mathrm{K}_{2} \mathrm{O}, \mathrm{TiO}_{2}, \mathrm{P}_{2} \mathrm{O}_{5}$ e $\mathrm{MnO}$ ) por ICPO-ES. Os elementos-traço (Ba, $\mathrm{Be}, \mathrm{Co}, \mathrm{Ga}, \mathrm{Hf}, \mathrm{Nb}, \mathrm{Rb}, \mathrm{Sr}$, $\mathrm{Ta}, \mathrm{Th}, \mathrm{U}, \mathrm{W}, \mathrm{Zr}$ e Y ), elementos terras raras - ETR ( $\mathrm{La}, \mathrm{Ce}, \mathrm{Pr}$, $\mathrm{Nd}, \mathrm{Sm}, \mathrm{Eu}, \mathrm{Gd}, \mathrm{Tb}, \mathrm{Dy}, \mathrm{Ho}, \mathrm{Er}, \mathrm{Tm}, \mathrm{Yb}$ e Lu), e metais preciosos e base ( $\mathrm{Cu}, \mathrm{Ni}, \mathrm{Pb}$ e $\mathrm{Zn}$ ) foram determinados por ICP-MS. O software utilizado para o tratamento dos dados e a confecção dos diagramas foi o GCDkit 3.00 (Janoušek et al., 2006).

\section{Granulito félsico}

Os dados geoquímicos das amostras do granulito félsico indicam ampla variação dos teores de $\mathrm{SiO}_{2}$, que os classifica como intermediários até ácidos, com teores, respectivamente, entre 58,2 e $74,4 \%$. De maneira semelhante, $\mathrm{o}_{2} \mathrm{O}_{3}$ varia de 13,2 a $17,4 \%$, e o $\mathrm{Fe}_{2} \mathrm{O}_{3(t)}$, de 1,4 a $7,5 \%$, enquanto o $\mathrm{MgO}$ apresenta valores altos (de 1,7 a 3,1\%) e baixos de $(0,2$ a $0,9 \%)$ para as rochas, respectivamente, intermediárias e ácidas.

Utilizando sílica como índice de diferenciação nos diagramas do tipo Harker (Figura 18), observam-se trends bem definidos com correlações negativas entre esse índice e $\mathrm{Al}_{2} \mathrm{O}_{3}$, $\mathrm{CaO}, \mathrm{Fe}_{2} \mathrm{O}_{3(\mathrm{t})}, \mathrm{MgO}, \mathrm{MnO}, \mathrm{P}_{2} \mathrm{O}_{5}$ e $\mathrm{TiO}_{2}$. Correlação positiva é identificada entre sílica e $\mathrm{K}_{2} \mathrm{O}$, sugerindo o enriquecimento em feldspato alcalino dos litotipos mais evolúídos, enquanto o $\mathrm{Na}_{2} \mathrm{O}$ apresentou dispersão, não estando inserido na Figura 18. Nos diagramas envolvendo sílica e elementos-traço, observa-se que $\mathrm{Ba}$, Th e $\mathrm{Rb}$ apresentam correlação positiva proporcional ao aumento de feldspato alcalino; enquanto $\mathrm{Sc}, \mathrm{Sr}$, $\mathrm{Ga}, \mathrm{V}$ e Y mostram correlação negativa, indicando a concentração de plagioclásio e minerais máficos nos litotipos menos diferenciados (Figura 19). Esses elementos têm, em geral, amplas variações, com valores referentes às rochas menos evoluídas para as mais diferenciadas: $\mathrm{Ba}(229,0-1.591,0$ $\mathrm{ppm}), \operatorname{Th}(0,2-10,3 \mathrm{ppm}), \mathrm{Rb}(10,1-160,0 \mathrm{ppm})$ e $\mathrm{Sc}(27,0$
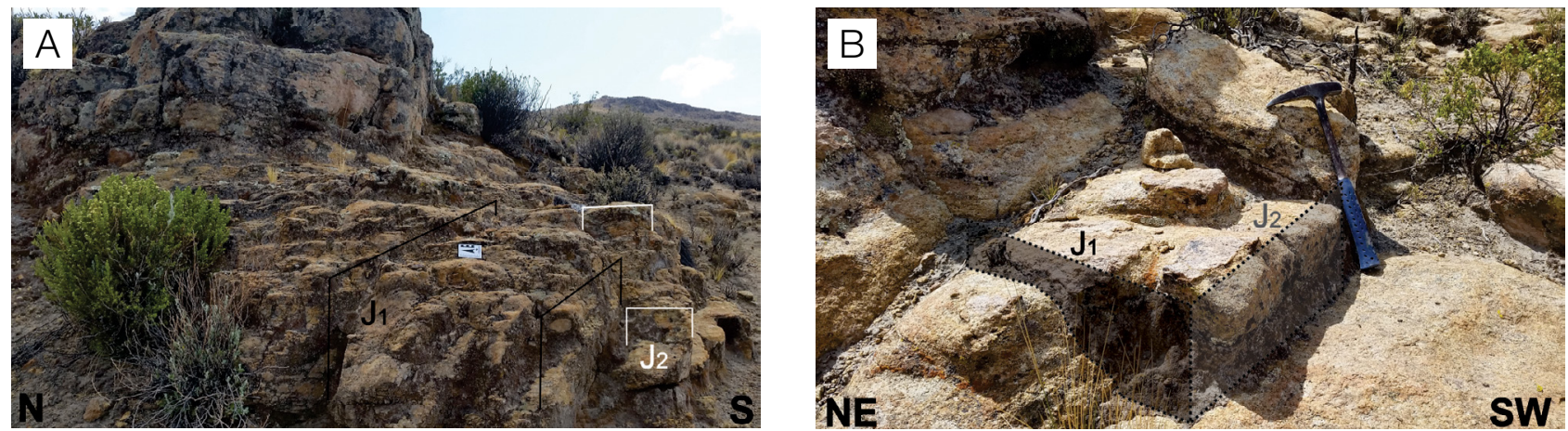

Figura 16. Clivagem disjuntiva $J_{1}$ e $J_{2}$. (A) Aspecto geral da disposição das clivagens disjuntivas. (B) clivagem disjuntiva $J_{1}$ (NEE-SWW) e $J_{2}$ (NNE-SSW).

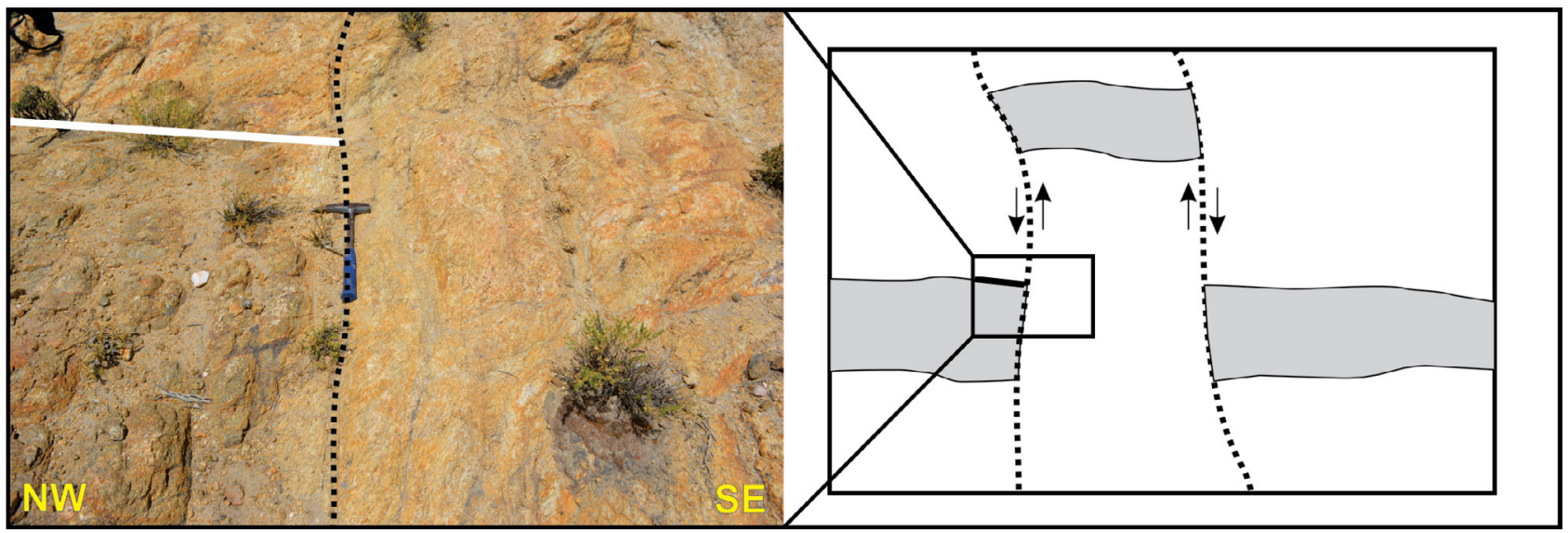

Figura 17. Foto e desenho esquemático mostrando o comportamento das falhas normais. 
$-3,0 \mathrm{ppm}), \mathrm{Sr}(515,9-177,3 \mathrm{ppm}), \mathrm{Ga}(18,5-11,1 \mathrm{ppm})$, $\mathrm{V}(130,0-23,0 \mathrm{ppm}), \mathrm{Y}(62,2-4,2 \mathrm{ppm})$.

Os dados geoquímicos do granulito félsico sugerem protólitos com ampla variação composicional, sendo classificados como diorito, tonalito, granodiorito e granito, no diagrama R1-R2 (De La Roche et al., 1980; Figura 20A), e como quartzo diorito, tonalito, granodiorito e granito, no diagrama P-Q (Debon e Le Fort, 1983; Figura 20B). São rochas,

Tabela 1. Composição química de elementos maiores, menores (peso \%) e traços (ppm) do Granulito Uyarani. Siglas de identificação das amostras: Uyarani Cerro - UC, UN, UY.

\begin{tabular}{|c|c|c|c|c|c|c|c|c|c|c|c|c|}
\hline Amostra & UN1422 & UC 004F & UC 21A & UY1337 & UC 19 & UC 009 & UC 17A & UC 16 & UC 10II & UC 001 & UC 007 & UN1421 \\
\hline Elementos & & & & Granulito & félsico & & & & Gra & nulito $\mathrm{m}$ & fico (enc & lave) \\
\hline $\mathrm{SiO}_{2}$ & 74,38 & 72,67 & 72,25 & 71,04 & 66,93 & 66,78 & 64,28 & 58,23 & 49,61 & 49,19 & 47,9 & 47,81 \\
\hline $\mathrm{TiO}_{2}$ & 0,34 & 0,35 & 0,25 & 0,41 & 0,54 & 0,53 & 0,61 & 0,87 & 1,07 & 1,23 & 0,86 & 0,73 \\
\hline $\mathrm{Al}_{2} \mathrm{O}_{3}$ & 13,33 & 13,97 & 14,44 & 14,35 & 15,30 & 14,64 & 15,66 & 17,45 & 17,83 & 19,96 & 10,88 & 15,91 \\
\hline $\mathrm{Fe}_{2} \mathrm{O}_{3}$ & 1,75 & 2,51 & 1,46 & 2,82 & 4,64 & 5,71 & 5,68 & 7,50 & 11,12 & 7,76 & 13,36 & 10,62 \\
\hline $\mathrm{MnO}$ & 0,01 & 0,04 & 0,04 & 0,07 & 0,10 & 0,12 & 0,09 & 0,15 & 0,22 & 0,18 & 0,24 & 0,21 \\
\hline $\mathrm{MgO}$ & 0,19 & 0,92 & 0,41 & 0,74 & 1,72 & 2,46 & 2,56 & 3,06 & 5,51 & 5,5 & 11,7 & 8,62 \\
\hline $\mathrm{CaO}$ & 1,25 & 2,52 & 1,47 & 2,68 & 4,21 & 4,24 & 5,50 & 7,32 & 7,79 & 11,05 & 11,05 & 11,02 \\
\hline $\mathrm{Na}_{2} \mathrm{O}$ & 2,89 & 3,51 & 3,38 & 3,89 & 3,61 & 4,16 & 3,55 & 3,80 & 4,6 & 3,52 & 2,24 & 2,87 \\
\hline $\mathrm{K}_{2} \mathrm{O}$ & 5,33 & 3,07 & 5,77 & 3,49 & 2,43 & 0,94 & 1,46 & 1,01 & 1,6 & 1,17 & 1,16 & 1,77 \\
\hline $\mathrm{P}_{2} \mathrm{O}_{5}$ & 0,14 & 0,1 & 0,06 & 0,13 & 0,16 & 0,14 & 0,19 & 0,28 & 0,34 & 0,2 & 0,13 & 0,17 \\
\hline LOI & 0,6 & 0,5 & 0,7 & 0,5 & 0,5 & 0,8 & 0,7 & 0,4 & 0,7 & 1,2 & 1,1 & 1,4 \\
\hline Total & 100,2 & 100,1 & 100,2 & 100,1 & 100,1 & 100,5 & 100,2 & 100,0 & 100,3 & 100,9 & 100,6 & 101,1 \\
\hline $\mathrm{Ba}$ & 987 & 681 & 1591 & 1080 & 772 & 229 & 490 & 374 & 403 & 193 & 1697 & 490 \\
\hline $\mathrm{Be}$ & 2,00 & 2,00 & 1,00 & 1,00 & 1,00 & 2,00 & 2,00 & 3,00 & 9,00 & 2,00 & 1,00 & 2,00 \\
\hline Co & 172 & 153,6 & 177,8 & 84,6 & 158,1 & 112,9 & 236,1 & 120,0 & 96,0 & 98,7 & 111,8 & 98,9 \\
\hline $\mathrm{Ga}$ & 11,10 & 14,70 & 13,30 & 14,20 & 14,80 & 16,30 & 1570 & 18,50 & 21,70 & 18,80 & 12,90 & 14,90 \\
\hline $\mathrm{Hf}$ & 3,50 & 2,80 & 4,40 & 4,60 & 5,00 & 2,40 & 4,30 & 4,80 & 2,50 & 3,00 & 1,70 & 1,30 \\
\hline $\mathrm{Nb}$ & 7,70 & 4,00 & 6,80 & 11,50 & 8,30 & 6,70 & 7,50 & 8,50 & 6,00 & 7,10 & 3,30 & 2,50 \\
\hline $\mathrm{Rb}$ & 120,3 & 63,8 & 160,0 & 80,6 & 55,4 & 10,1 & 389 & 16,7 & 60,7 & 12,3 & 13,1 & 77,3 \\
\hline $\mathrm{Sr}$ & 177,3 & 376,3 & 323,7 & 328,6 & 489,2 & & & & 422,3 & & & 298,7 \\
\hline Ta & 0,60 & 0,40 & 0,70 & 0,90 & 0,80 & 0,60 & 0,80 & 0,60 & 0,40 & 0,60 & 0,30 & 0,30 \\
\hline Th & 10,30 & 1,00 & 7,20 & 1,10 & 1,70 & 0,20 & 1,00 & 0,20 & 2,10 & 2,90 & 1,70 & 1,50 \\
\hline$U$ & 0,30 & 0,10 & 0,10 & 0,20 & 0,10 & 0,10 & 0,20 & 0,10 & 0,40 & 0,70 & 0,30 & 0,40 \\
\hline W & 1013,1 & 857,4 & 987,6 & 506,4 & 853,2 & 542,3 & 1225 & & 327,5 & & 226,7 & 287,6 \\
\hline $\mathrm{Zr}$ & 150,3 & 108,2 & & & & & & & 80,9 & & & 41,4 \\
\hline$Y$ & 13,40 & 4,20 & 12,40 & 62,20 & 19,50 & 14,60 & 22,40 & 33,10 & 26,00 & 34,40 & 17,40 & 22,50 \\
\hline $\mathrm{Pb}$ & 2,00 & 1,00 & 2,80 & 1,20 & 1,30 & 1,00 & 1,30 & 1,50 & 1,80 & 2,00 & 1,10 & 1,50 \\
\hline La & 51,30 & 22,80 & 33,90 & 38,00 & 28,00 & 33,80 & 27,00 & 27,20 & 34,40 & 27,50 & 26,70 & 14,10 \\
\hline $\mathrm{Ce}$ & 102,30 & 36,90 & 60,10 & 86,30 & 55,60 & 64,90 & 57,40 & 62,80 & 81,40 & 54,80 & 55,20 & 21,00 \\
\hline $\operatorname{Pr}$ & 10,80 & 3,33 & 5,62 & 10,13 & 5,68 & 6,29 & 6,53 & 8,11 & 9,25 & 7,40 & 5,96 & 3,26 \\
\hline $\mathrm{Nd}$ & 38,20 & 11,40 & 19,00 & 42,20 & 22,90 & 23,40 & 25,50 & 36,80 & 34,70 & 30,40 & 21,70 & 14,10 \\
\hline Sm & 6,52 & 1,75 & 3,00 & 9,65 & 3,92 & 3,74 & 5,29 & 7,60 & 6,73 & 6,14 & 4,00 & 3,09 \\
\hline Eu & 0,89 & 0,75 & 1,23 & 1,54 & 1,11 & 1,04 & 1,19 & 1,98 & 2,02 & 1,79 & 1,06 & 0,91 \\
\hline $\mathrm{Gd}$ & 4,99 & 1,31 & 2,65 & 9,95 & 3,78 & 3,36 & 4,75 & 7,05 & 5,51 & 6,11 & 3,54 & 3,68 \\
\hline $\mathrm{Tb}$ & 0,65 & 0,16 & 0,40 & 1,77 & 0,53 & 0,51 & 0,71 & 1,10 & 0,81 & 1,00 & 0,57 & 0,63 \\
\hline Dy & 3,10 & 1,01 & 2,22 & 10,65 & 3,18 & 2,74 & 4,16 & 6,15 & 4,98 & 5,92 & 3,24 & 3,94 \\
\hline Ho & 0,51 & 0,15 & 0,46 & 2,31 & 0,70 & 0,55 & 0,84 & 1,30 & 0,92 & 1,18 & 0,68 & 0,81 \\
\hline Er & 1,18 & 0,48 & 1,43 & 6,57 & 2,08 & 1,53 & 2,59 & 3,89 & 2,65 & 3,47 & 1,91 & 2,31 \\
\hline Tm & 0,14 & 0,07 & 0,20 & 1,00 & 0,33 & 0,23 & 0,37 & 0,54 & 0,43 & 0,53 & 0,29 & 0,35 \\
\hline $\mathrm{Yb}$ & 0,86 & 0,46 & 1,35 & 6,25 & 2,06 & 1,44 & 2,27 & 3,36 & 2,96 & 3,40 & 1,93 & 2,05 \\
\hline Lu & 0,11 & 0,08 & 0,20 & 0,87 & 0,34 & 0,23 & 0,35 & 0,54 & 0,50 & 0,56 & 0,30 & 0,36 \\
\hline $\mathrm{Eu} / \mathrm{Eu}^{\star}$ & 0,48 & 1,52 & 1,34 & 0,48 & 0,89 & 0,90 & 0,73 & 0,83 & 1,02 & 0,90 & 0,87 & 0,83 \\
\hline (La/Yb)n & 39,90 & 33,10 & 16,80 & 4,10 & 9,10 & 15,70 & 8,00 & 5,40 & 7,80 & 5,40 & 9,30 & 4,60 \\
\hline
\end{tabular}


principalmente, metaluminosas com termos graníticos peraluminosos, como ilustrado na Figura 20C, que corresponde ao diagrama $\mathrm{A} / \mathrm{NK}$ versus $\mathrm{A} / \mathrm{CNK}$, proposto por Maniar e Piccoli (1989), a partir dos índices de Shand. No diagrama $\mathrm{SiO}_{2}$ versus $\mathrm{FeOt} / \mathrm{MgO}$ (Miyashiro, 1974; Figura 20D), as amostras plotam no campo de séries cálcio-alcalinas, classificação corroborada pelo diagrama AFM (Figura 20E), de Irvine e Baragar (1971), que descreve um trend de enriquecimento em álcalis e empobrecimento em ferro e magnésio. $\mathrm{O}$ diagrama discriminante de tectônica de granitos de Frost et al. (2001; Figura 20F) mostra que se tratam de granitoides magnesianos.

Os diagramas discriminantes $\mathrm{Rb}$ versus $\mathrm{Y}+\mathrm{Nb}$ e $\mathrm{Rb}$ versus $\mathrm{Ta}+\mathrm{Yb}$, propostos por Pearce et al. (1984, Figura 21A e 21B), assim como o diagrama Hf-Rb/30-3Ta (Harris et al., 1986; Figura 21C) sugerem que os protólitos do granulito félsico do Granulito Uyarani foram gerados em arcos vulcânicos (VAG).

Os padrões de distribuição dos ETR, normalizados pelos valores condríticos de Nakamura (1977; Figura 21D), exibem
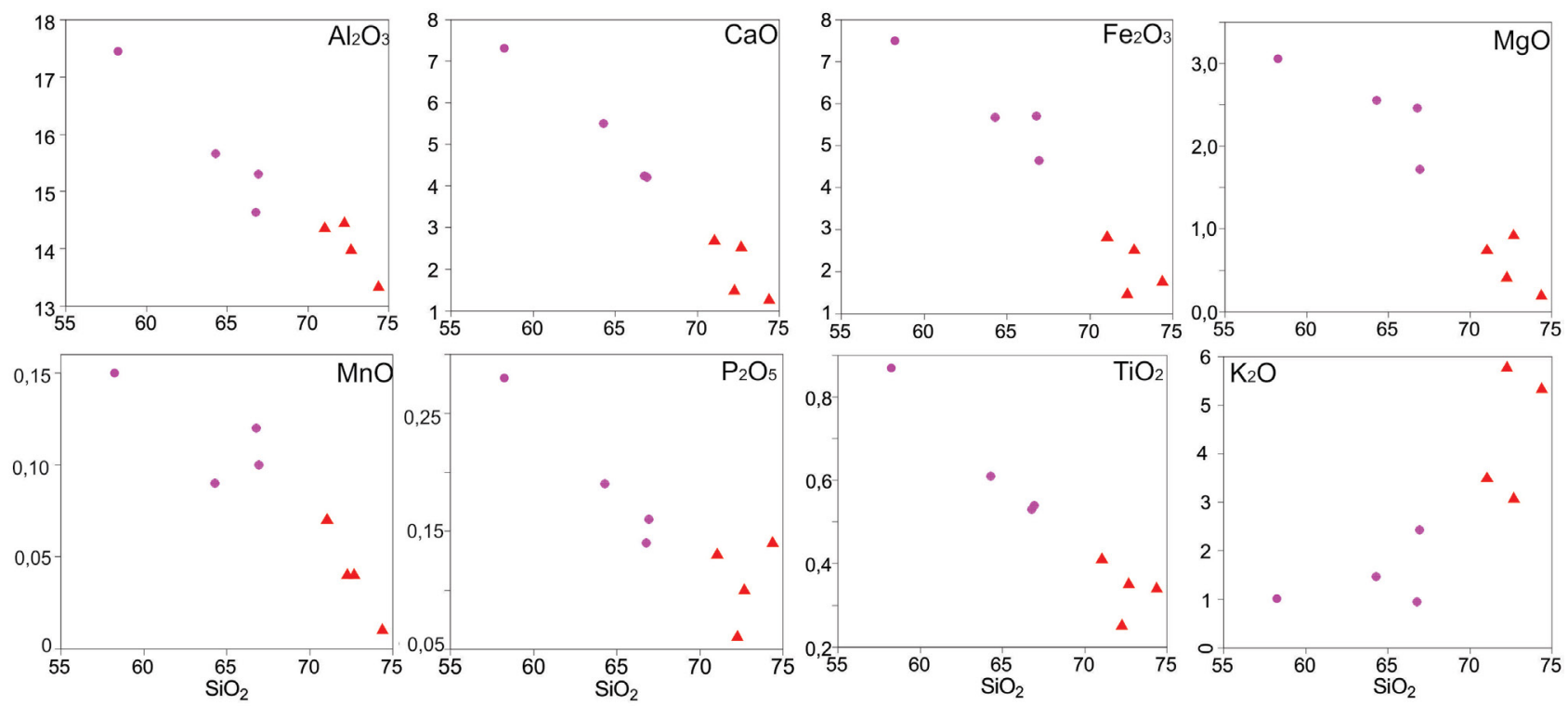

granitos e granodioritos

granodioritos e diorito

Figura 18. Diagramas de Harker de elementos maiores, expressos em óxidos (\%) para as amostras do granulito félsico.
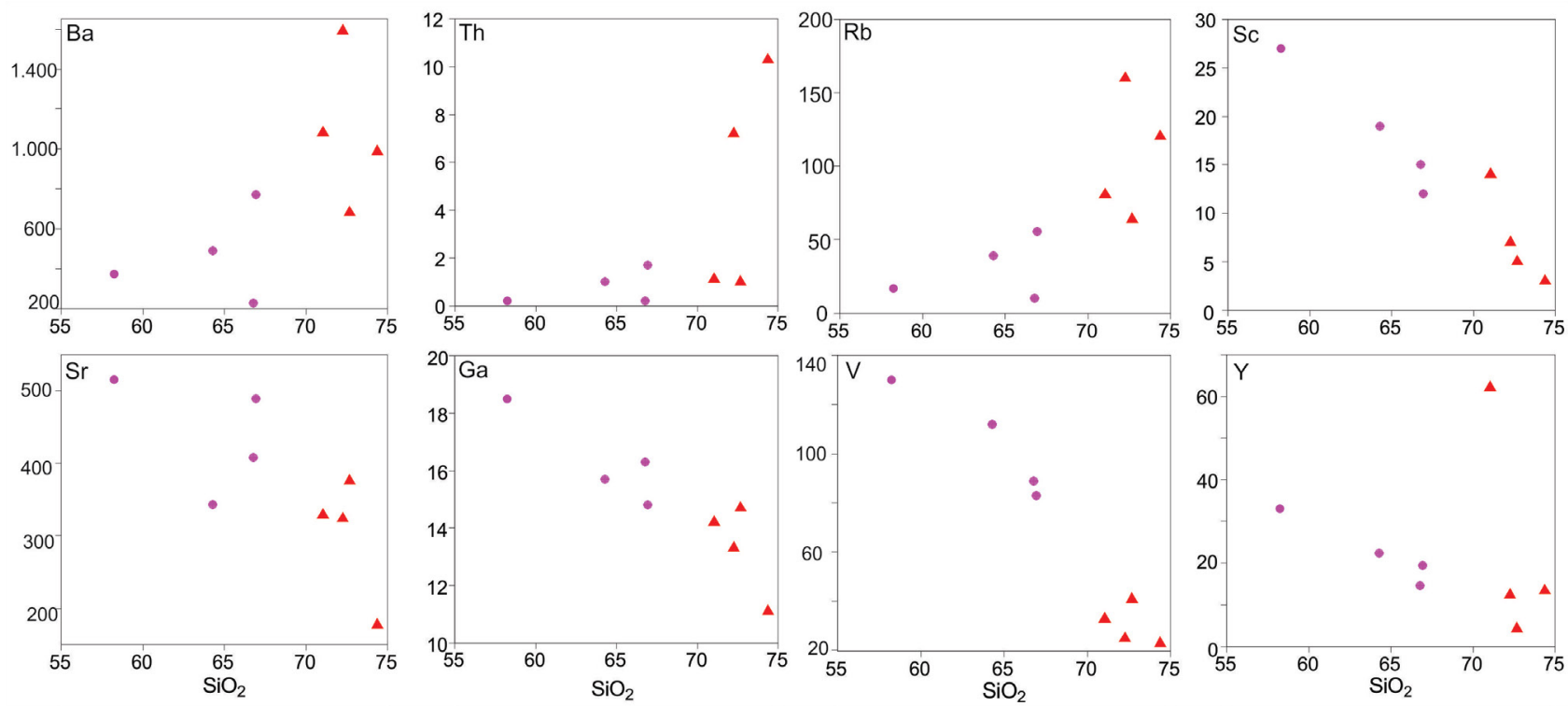

Figura 19. Diagrama de Harker de elementos traço, expressos em ppm, para o granulito félsico. 
um enriquecimento dos ETRL em comparação aos ETRP, com razões $(\mathrm{La} / \mathrm{Yb}) \mathrm{n}$ entre 4,10 e 39,9. Observa-se nessa figura uma distribuição similar para a maioria das amostras, à exceção do Eu, cuja razão Eu/Eu* varia entre 0,48 e 1,52, com anomalias negativas para duas amostras, evidenciando fracionamento de plagioclásio, e positivas para outras duas; nas demais amostras não foram verificadas anomalias de $\mathrm{Eu}$, o que pode sugerir a retenção de plagioclásio no líquido.

A distribuição de elementos-traço e $\mathrm{K}_{2} \mathrm{O}$, normalizados pelos granitos de Cordilheira Meso-oceânica (Pearce et al., 1984; Figura 21E), aponta que existe um enriquecimento de elementos LILE, em relação aos elementos de alto potencial iônico (HFSE). Observam-se também, nessa configuração, anomalias negativas de $\mathrm{Ta}$ e $\mathrm{Nb}$, corroborando a hipótese de ambiente de arco magmático para a colocação dos protólitos dos granulitos estudados.

\section{Granulito máfico (enclaves)}

Os enclaves do Granulito Uyarani, descritos petrograficamente como granulito máfico, apresentam baixos teores de $\mathrm{SiO}_{2}$ e variam entre 47,81 e $49,61 \%$. Os outros óxidos têm teores variáveis: $\mathrm{Fe}_{2} \mathrm{O}_{3}$ de 7,76 a 13,36 \%; $\mathrm{TiO}_{2}$ de 0,73 a $1,2 \% ; \mathrm{Na}_{2} \mathrm{O}$ de 2,2 a $4,6 \% ; \mathrm{Al}_{2} \mathrm{O}_{3}$ de 10,88 a $19,96 \%$; $\mathrm{MgO}$ de 5,5 a $11,7 \%$ e $\mathrm{K}_{2} \mathrm{O}$ de 1,16 a $1,7 \%$. O índice de magnésio (mg\#) das amostras estudadas, calculado como $\mathrm{mg} \#=\mathrm{Mg}^{+2} /\left(\mathrm{Mg}^{+2}+\mathrm{Fe}^{+2}\right)$, varia entre 0,30 e 0,44 , sugerindo envolvimento de magma basáltico mais evoluído. Os dados analíticos dessas rochas coincidem com os campos dos gabros/monzogabros e do domínio da série cálcio-alcalina, respectivamente, nos diagramas Q-P (Debon e Le Fort, 1983; Figura 22A) e AFM (Miyashiro, 1974; Figura 22B).

Os diagramas discriminantes de ambiente tectônico $10 \mathrm{MnO}^{-\mathrm{TiO}_{2}}-10 \mathrm{P}_{2} \mathrm{O}_{5}$ (Figura $23 \mathrm{~A}$ ) e $\mathrm{Zr}-\mathrm{Ti} / 100-\mathrm{Sr} / 2$ (Figura 23B), propostos, respectivamente, por Mullen (1983) e Pearce e Cann (1973) sugerem que os protólitos do granulito máfico devem corresponder principalmente a basaltos cálcio-alcalinos $(\mathrm{CAB})$ e podem ter sido formados em ambiente de arco magmático; o que é corroborado nos diagramas de Wood (1980) que utilizam elementos-traço (Zr, Th, Hf, Ta e Nb; Figuras 23C, 23D e 23E).

O diagrama de elementos-traço, normalizados pelo manto primitivo (McDonough e Sun, 1995; Figura 24A), mostra anomalias negativas em $\mathrm{Rb}, \mathrm{K}, \mathrm{Nb}$ e $\mathrm{Zr}$. Os padrões
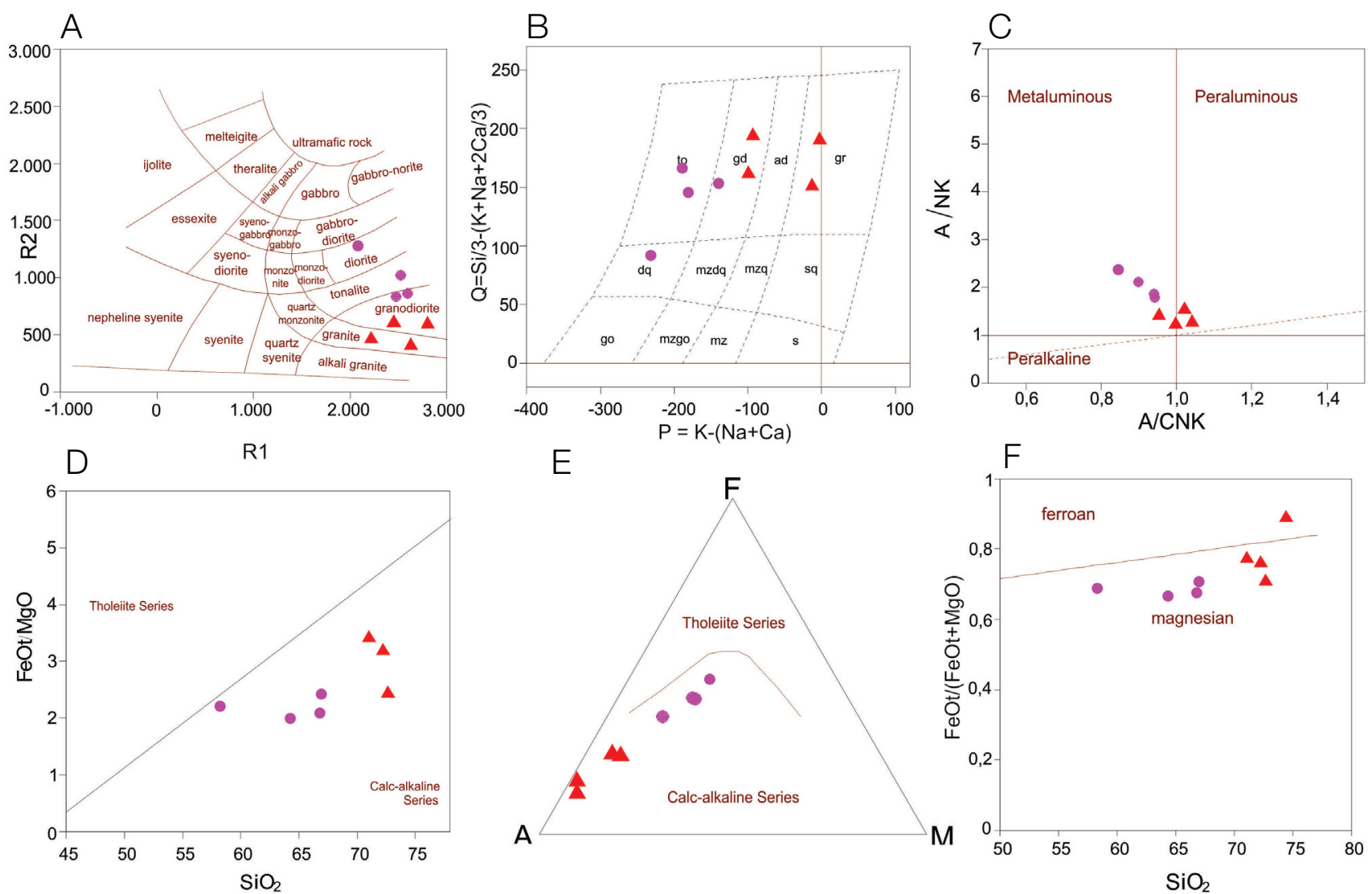

Figura 20. Diagramas classificatórios para o granulito félsico do Granulito Uyarani. (A) $R_{1}$ versus $R_{2}$ (De La Roche et al., 1980); (B) P-Q (Debon e Le Fort, 1983); (C) A/NK versus A/CNK (Maniar e Piccoli, 1989); (D) $\mathrm{SiO}_{2}$ versus FeOt/MgO (Miyashiro, 1974); (E) AFM (Irvine e Baragar, 1971); (F) FeOt/(FeOt+ MgO) versus $\mathrm{SiO}_{2}$ (Frost et al., 2001). 
de distribuição dos ETR normalizados por valores condríticos de Boynton (1984; Figura 24B) exibem enriquecimento dos ETR leves em relação aos ETR pesados, com razões
$(\mathrm{La} / \mathrm{Yb}) \mathrm{n}$ entre 4,6 e 9,3, e com discreta anomalia negativa de $\mathrm{Eu}$ em duas amostras, com razões Eu/Eu* variando entre 0,83 e 1,02 .

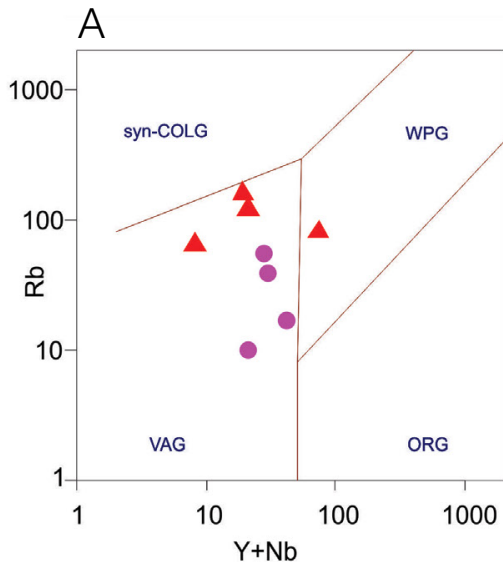

D 1.000

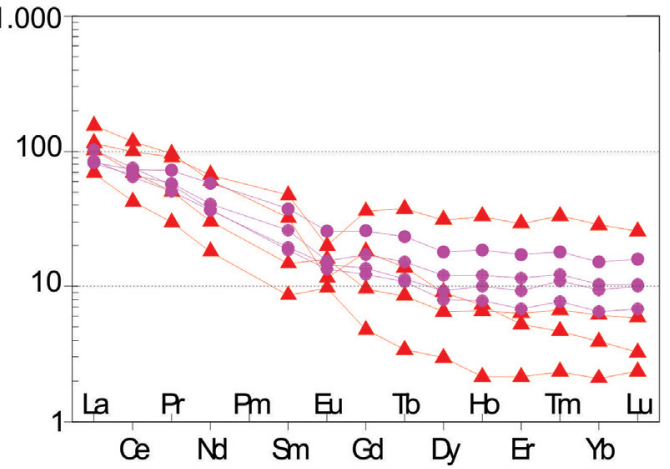

B

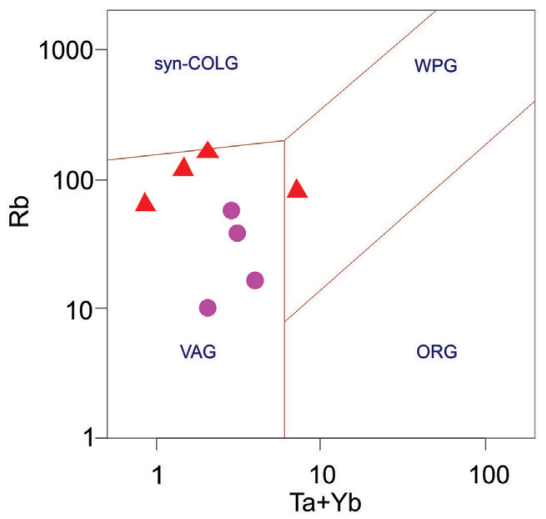

C

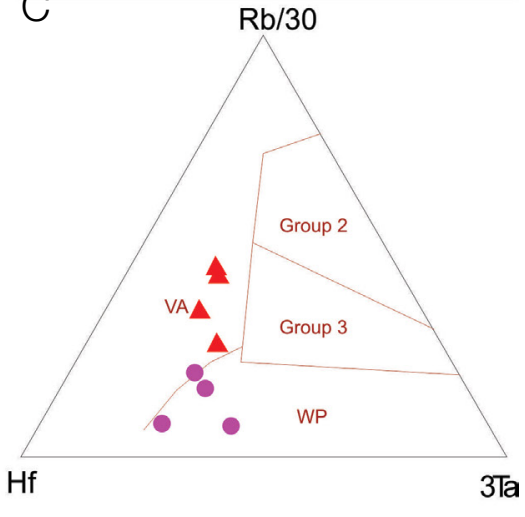

Figura 21. Diagramas para o granulito félsico do Granulito Uyarani. (A) $\mathrm{Rb}$ versus $\mathrm{Y}+\mathrm{Nb}$; (B) $\mathrm{Rb}$ versus $\mathrm{Ta}+\mathrm{Yb}$ propostos por Pearce et al. (1984); (C) Hf-Rb/30-3Ta (Harris et al., 1986); (D) ETR normalizados pelos valores condríticos (Nakamura, 1977); (E) elementos-traço e $\mathrm{K}_{2} \mathrm{O}$ normalizados pelos valores de granitos de Cordilheira Meso-oceânica (Pearce et al., 1984).
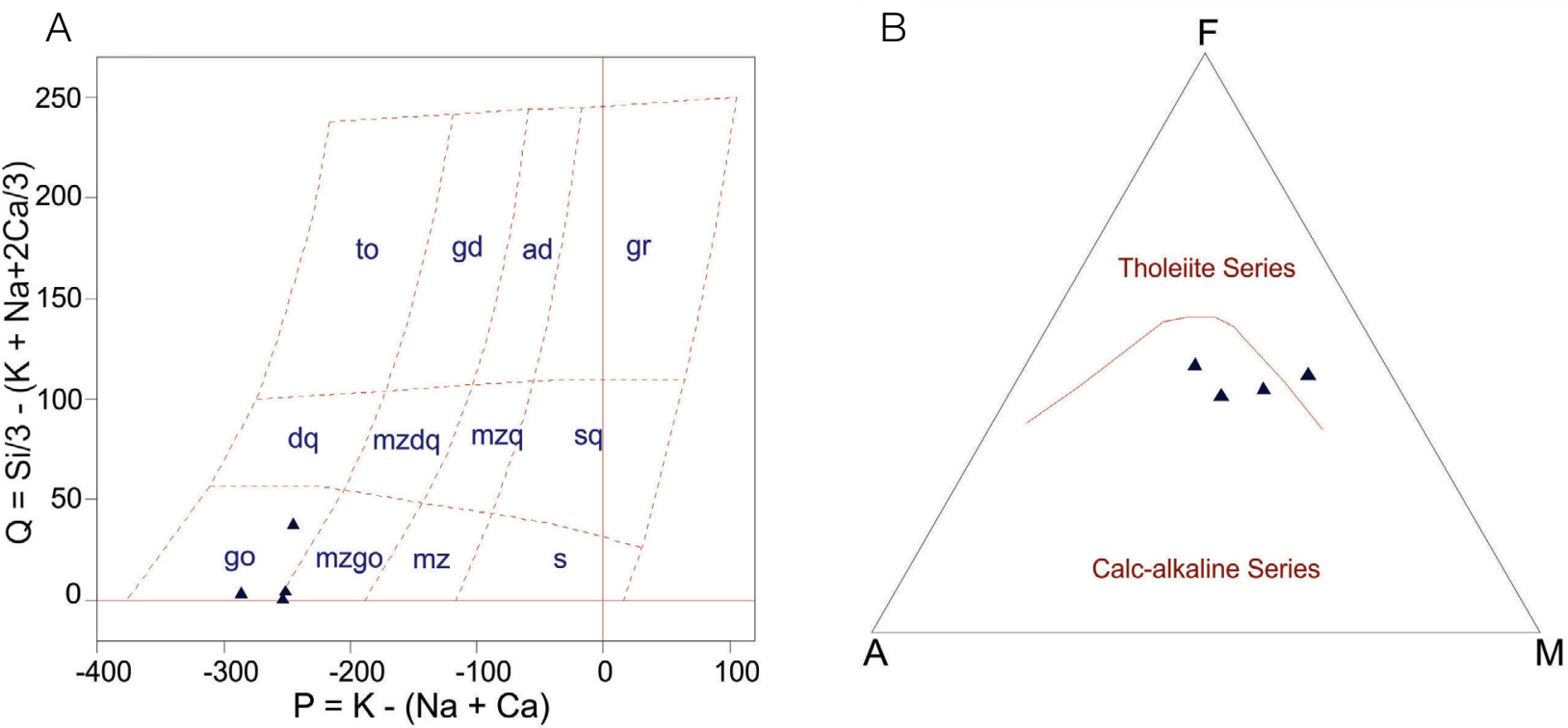

Figura 22. Diagramas classificatórios para o granulito máfico. (A) Q-P (Debon e Le Fort, 1983); (B) AFM (Miyashiro, 1974). 

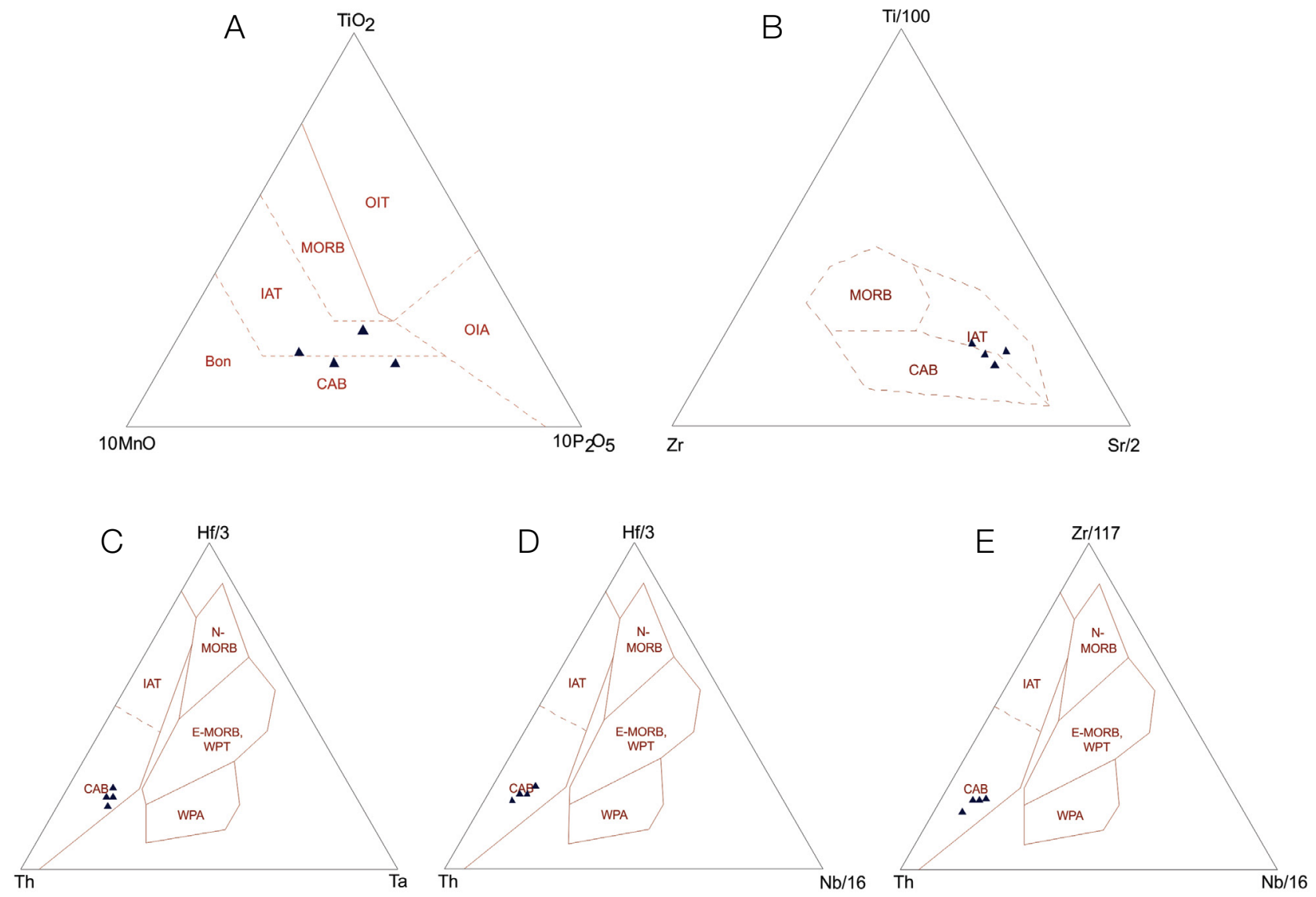

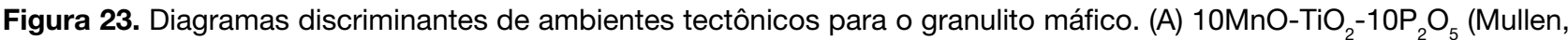
1983); (B) Zr-Ti/100-Sr/2 (Pearce e Cann, 1973); (C) Th-Hf/3-Ta; (D) Th-Hf/3-Nb/16; e (E) Th-Zr/117-Nb/16 propostos por Wood (1980).

A

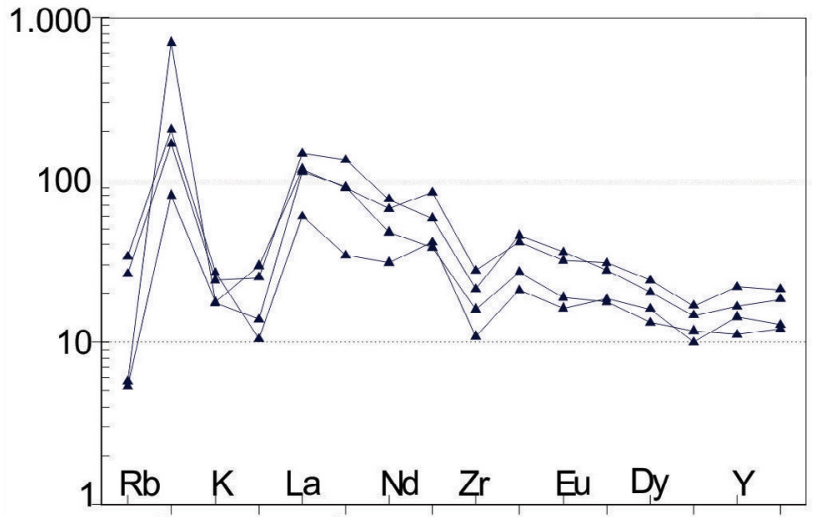

$\mathrm{Ba} \mathrm{Nb} \quad \mathrm{Ce} \mathrm{Sr} \quad \mathrm{Sm}$ Gd $\mathrm{Ti} \quad \mathrm{Yb}$
$B$

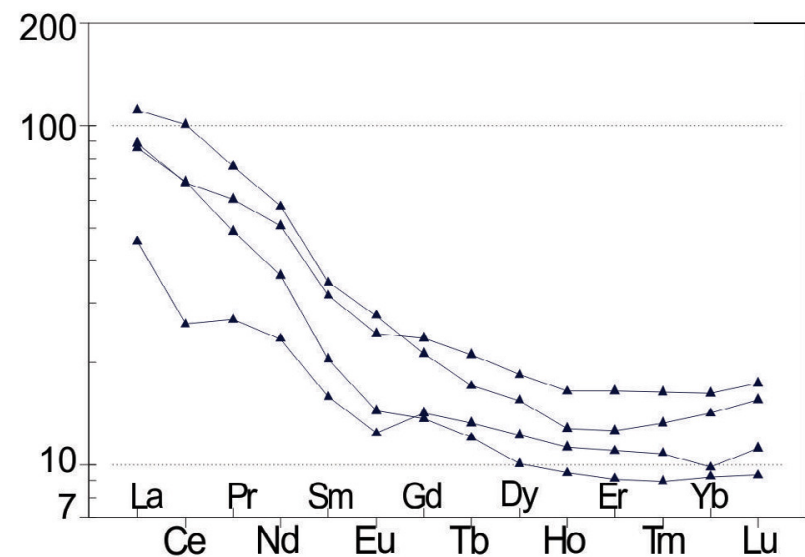

Figura 24. Diagrama multielementar e elementos terras raras para o granulito máfico. (A) Normalizados pelo manto primitivo (McDonough e Sun, 1995); (B) normalizadas por condritos (Boynton, 1984). 


\section{GEOCRONOLOGIA U-PB (SHRIMP)}

A amostra (UY1337) escolhida para datação foi o granulito félsico de cor cinza claro rosada, granulação média, com níveis máficos subordinados, classificado petrograficamente como sienogranito.

A amostra foi tratada no Laboratório de Preparação (UFMT) com a utilização de métodos convencionais de britagem, moagem e peneiramento; os minerais pesados foram separados por bateia, posteriormente a amostra foi secada e utilizou-se de ímã para a separação de grande parte dos minerais magnéticos. As populações de zircões foram obtidas com a utilização do separador magnético Frantz e os zircões foram selecionados com o uso de estereoscópio binocular, sendo enviados para análise 100 grãos de zircão.

Dos 100 grãos de zircão, foram escolhidos por meio do microscópio óptico os cristais mais adequados. Foram analisados 14 cristais (pequenos, rosados e translúcidos) e poucos deles estavam quebrados. A imagem CL obtida com o auxílio do microscópio de varredura eletrônica (MEV) mostra que sete cristais analisados tinham formatos piramidais e sete eram arredondados, sendo que o zoneamento é mais evidente nos cristais piramidais (Figura 25).

A Tabela 2 revela os dados analíticos com as razões isotópicas dos zircões datados. As análises foram realizadas pelo método geocronológico U-Pb (SHRIMP), no Centro de Pesquisa Geocronológica da Universidade de São Paulo (CPG-USP).

As idades foram calculadas com o uso do software Isoplot $^{\oplus}$ e representadas em diagramas concórdia (Figura 26). $\mathrm{O}$ diagrama concórdia revela uma idade de intercepto superior de $1.722 \pm 30 \mathrm{Ma}$ e uma idade concórdia de $1.736 \pm 5.1 \mathrm{Ma}$, interpretada como idade de cristalização do protólito ígneo. Os grãos de zircão analisados fornecem idades variando entre 1.295 e $1.751 \mathrm{Ma}$.

\section{DISCUSSÕES E CONCLUSÕES}

O embasamento pré-andino é formado por terrenos pré-cambrianos expostos em janelas estruturais, sendo o Granulito Uyarani uma ocorrência dessa natureza no Altiplano Andino, na porção oeste da Bolívia. Trata-se de uma exposição em uma serra de pequeno porte, com extensão em torno de 32 $\mathrm{km}^{2}$, que está aparentemente associada à Falha de San Andrés, encontrando-se parcialmente recoberta pelos ignimbritos da Formação Pérez.

As rochas do Granulito Uyarani, unidade estratigráfica definida neste trabalho, são divididas, petrograficamente, em granulitos félsicos dominantes e granulitos máficos que
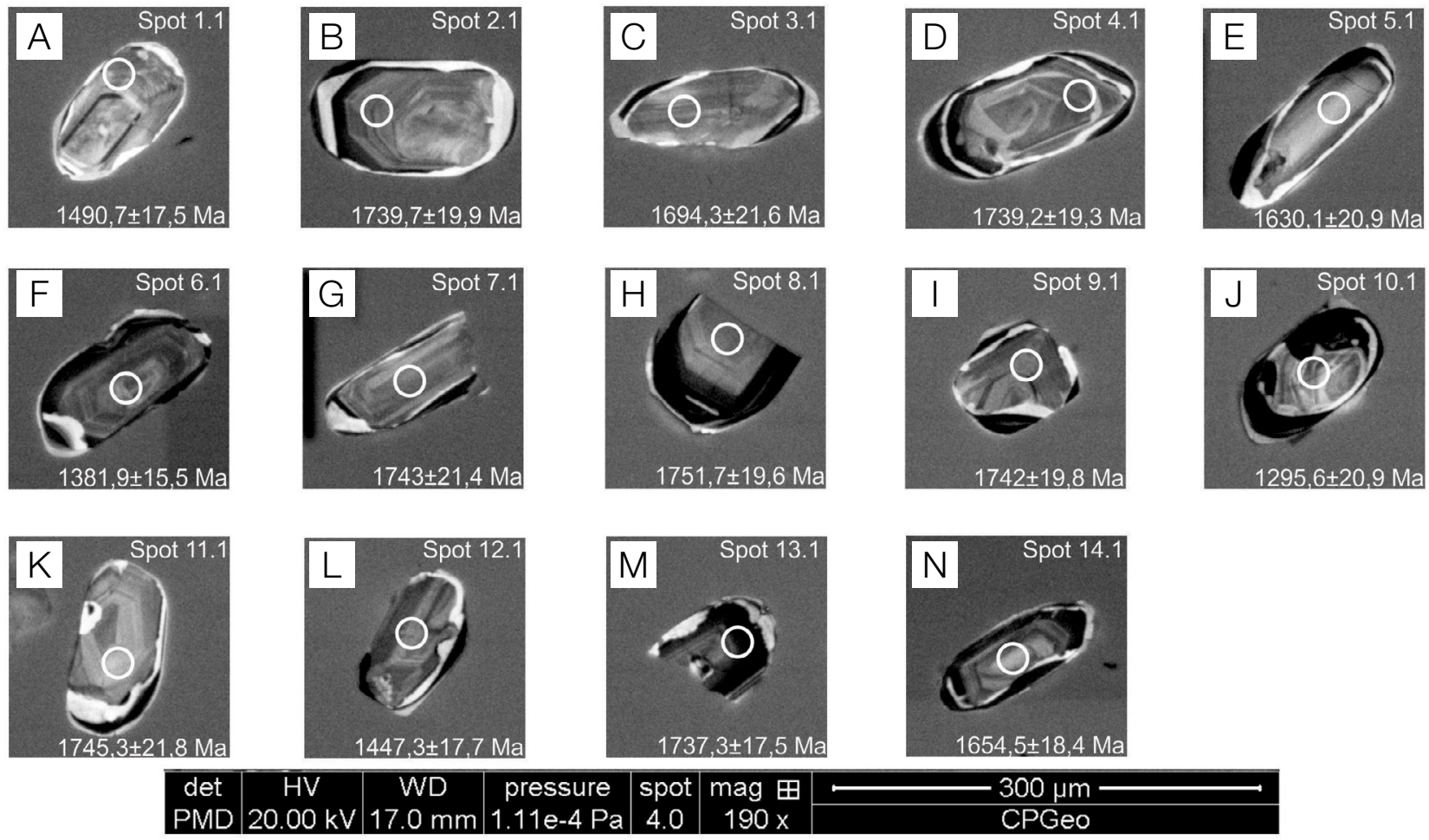

Figura 25. Imagem de microscopia eletrônica de varredura (catodoluminescência) dos grãos de zircão da amostra UY1337. A imagem também ilustra os pontos de aplicação do feixe primário ionizante ou spot. 
ocorrem como enclaves de até $5 \mathrm{~m}$ de comprimento. Embora os granulitos máficos tenham sido descritos por Troeng et al. (1994) e Wörner et al. (2000), não haviam sido caracterizados como enclaves.

É possível nomear detalhadamente os granulitos, usando o nome raiz e a respectiva mineralogia. A banda félsica do granulito félsico é constituída por biotita-hiperstênio granulito e a banda máfica é composta por hiperstênio \pm hornblenda granulito com granada. O granulito máfico é classificado como hornblenda-hiperstênio granulito.

A análise estrutural demonstra o caráter polideformado das rochas do Granulito Uyarani, com registro de, pelo menos, três fases de deformação $-F_{1}$ (bandamento $S_{1}$ ), $\mathrm{F}_{2}$ (xistosidade $\mathrm{S}_{2}$ e dobras recumbentes $\mathrm{D}_{2}$ ) e $\mathrm{F}_{3}$ (dobras abertas $\mathrm{D}_{3}$ ), bem como a existência de tectônica rúptil marcada por fraturas e falhas coincidentes com a orientação da terceira fase de deformação. As duas primeiras fases deformacionais são atribuídas à evolução estrutural pré-cambriana, sendo a $\mathrm{F}_{2}$ vinculada à Orogenia Sunsás, conforme idades Ar-Ar e Sm-Nd discutidas a seguir. É possível que as dobras abertas e as falhas reversas descritas na fase $\mathrm{F}_{3}$ sejam manifestações tectônicas relacionadas à evolução do Cinturão Andino.

Duas paragêneses metamórficas, $M_{1}$ e $M_{2}$, são atribuídas a essas rochas. $M_{1}$ é relacionada à primeira fase de deformação $\left(\mathrm{F}_{1}\right)$, responsável pelo desenvolvimento do bandamento gnáissico, alcançando condições metamórficas de fácies granulito para o conjunto de rochas máficas e félsicas,

Tabela 2. Síntese dos dados isotópicos U-Pb (SHRIMP) em zircões da amostra UY1337.

\begin{tabular}{|c|c|c|c|c|c|c|c|c|c|c|c|c|c|c|c|c|c|c|c|c|c|c|c|c|c|}
\hline spot & $\stackrel{\mathrm{ppm}}{\mathrm{U}}$ & $\begin{array}{c}\mathrm{ppm} \\
\mathrm{Th}\end{array}$ & $\begin{array}{l}\text { Razão } \\
\text { Th/U }\end{array}$ & $\begin{array}{l}\text { ppm } \\
\text { Rad } \\
206 \mathrm{~b}\end{array}$ & $\begin{array}{l}204 \\
/ 206\end{array}$ & $\begin{array}{l}\% \\
\text { err }\end{array}$ & $\begin{array}{c}\% \\
\text { comm } \\
206\end{array}$ & $\begin{array}{l}\text { Total } \\
238 \\
/ 206\end{array}$ & $\begin{array}{l}\% \\
\text { err }\end{array}$ & $\begin{array}{l}\text { Total } \\
207 \\
/ 206\end{array}$ & $\begin{array}{l}\% \\
\text { err }\end{array}$ & $\begin{array}{l}238 \\
/ 206 r\end{array}$ & $\begin{array}{l}\% \\
\text { err }\end{array}$ & $\begin{array}{l}207 r \\
/ 206 r\end{array}$ & $\begin{array}{l}\% \\
\text { err }\end{array}$ & $\begin{array}{c}207 r / \\
235\end{array}$ & $\begin{array}{l}\% \\
\text { err }\end{array}$ & $\begin{array}{l}206 r \\
/ 238\end{array}$ & $\begin{array}{l}\% \\
\text { err }\end{array}$ & $\begin{array}{l}\text { err } \\
\text { corr }\end{array}$ & $\begin{array}{c}204 \mathrm{corr} \\
206 \mathrm{~Pb} / \\
238 \mathrm{U}\end{array}$ & $\begin{array}{l}1 \sigma \\
\text { err }\end{array}$ & $\begin{array}{l}204 \text { corr } \\
207 \mathrm{~Pb} / \\
206 \mathrm{~Pb}\end{array}$ & $\begin{array}{l}1 \sigma \\
\text { err }\end{array}$ & $\begin{array}{c}\% \\
\text { Disc }\end{array}$ \\
\hline .1 & 186 & 117 & & 41,7 & $3,0 \mathrm{E}-4$ & 20 & 0,49 & 3,82 & 3 & 1032, & 1,0 & 3,84 & 1,3 & & 1,5 & 55 & 2,0 & 2602 & 1,3 & 663 & 1490,7 & 17,5 & 1604 & 28 & 8 \\
\hline. .1 & 183 & 118 & 67 & 49,0 & 2E-4 & 22 & 35 & 3,21 & 1,3 & 1072, & 4 & 3,23 & 1,3 & 041 & ,6 & 45 & , 1 & 3098 & 1,3 & ,627 & 739,7 & 19,9 & 699 & 30 & -2 \\
\hline 3.1 & 136 & 86 & 0,66 & 35,1 & $1,3 \mathrm{E}-4$ & 35 & 0,20 & 3,32 & 1,4 & 1075, & 1,1 & 3,33 & 1,4 & 1058, & 1,3 & 4,39 & 1,9 & 3006, & 1,4 & ,755 & 1694,3 & 21,6 & 1728 & 23 & 2 \\
\hline .1 & 212 & 61 & 30 & 56,7 & $1,6 \mathrm{E}-4$ & 24 & 0,25 & 3,22 & 1,3 & 1065, & 0,8 & 3,23 & 1,3 & 1043, & 1,0 & 4,46 & 1,6 & 3097, & 1,3 & ,778 & 1739,2 & 19,3 & 1703 & 19 & -2 \\
\hline .1 & 106 & 65 & 0,64 & 26,1 & 5,3E-5 & 82 & 0,08 & 3,47 & 1,4 & 1039, & 1,3 & 3,48 & 1,4 & 1031, & 1,4 & 4,09 & 2,0 & 2877, & 1,5 & ,719 & 1630,1 & 20,9 & 1681 & 26 & 3 \\
\hline 61 & 351 & 226 & 0,67 & 72,2 & $1,1 \mathrm{E}-4$ & 25 & 0,18 & 4,17 & 1,2 & 0939, & 0,8 & 4,18 & 1,2 & 0924, & 0,9 & 3,05 & 1,6 & 2391 & 1,2 & ,801 & 1381,9 & 15,5 & 1475 & 18 & 7 \\
\hline .1 & 146 & 119 & 0,84 & 39,0 & $1,0 \mathrm{E}-4$ & 54 & 0,16 & 3,21 & 1,4 & 1085, & 1,0 & 3,22 & 1,4 & 1071, & 1,2 & 4,58 & 1,9 & 3105, & 1,4 & ,745 & 1743,0 & 21,4 & 1751 & 23 & 0 \\
\hline 3.1 & 195 & 151 & 0,80 & 52,5 & $6,0 \mathrm{E}-5$ & 55 & 0,09 & 3,20 & 1,3 & 1077, & 1,9 & 3,20 & 1,3 & 1068, & 2,0 & 4,60 & 2,3 & 3122 & 1,3 & ,548 & 1751,7 & 19,6 & 1746 & 36 & 0 \\
\hline .1 & 177 & 141 & 0,82 & 47,4 & $2,4 \mathrm{E}-4$ & 21 & 0,38 & 3,21 & 1,3 & 1103, & 0,9 & 3,22 & 1,3 & 1070, & 1,2 & 4,58 & 1,8 & 3103, & 1,3 & ,728 & 1742,0 & 19,8 & 1749 & 22 & 0 \\
\hline 0.1 & 158 & 98 & 0,64 & 30,3 & $6,8 \mathrm{E}-5$ & 56 & 0,11 & 4,49 & 1,8 & 0919, & 1,8 & 4,49 & 1,8 & 0909, & 2,0 & 2,79 & 2,7 & 2226 & 1,8 & ,671 & 1295,6 & 20,9 & 1445 & 37 & 12 \\
\hline 11.1 & 108 & 57 & 0,55 & 28,8 & $8,6 \mathrm{E}-5$ & 24 & 0,13 & 3,21 & 1,4 & 1092, & 1,2 & 3,22 & 1,4 & 1080, & 1,2 & 4,63 & 1,9 & 3109, & 1,4 & ,757 & 1745,3 & 21,8 & 1767 & 22 & 1 \\
\hline 2.1 & 170 & 139 & 0,85 & 36,8 & $1,0 \mathrm{E}-4$ & 45 & 0,17 & 3,97 & 1,4 & 0948, & 1,1 & 3,97 & 1,4 & 0934, & 1,3 & 3,24 & 1,9 & 2517, & 1,4 & ,719 & 1447,3 & 17,7 & 1496 & 25 & 3 \\
\hline 3.1 & 610 & 472 & 0,80 & 62,3 & $2,2 E-5$ & 27 & 0,03 & 3,23 & 1,1 & 1060, & 0,5 & 3,23 & 1,1 & 1057, & 0,5 & 4,51 & 1,2 & 3093, & 1,1 & 921 & 1737,3 & 17,5 & 1727 & 9 & -1 \\
\hline 14.1 & 202 & 179 & 0,92 & 51,2 & $3,1 \mathrm{E}-4$ & 18 & 0,48 & 3,40 & 1,3 & 1057, & 0,9 & 3,41 & 1,3 & 1015, & 1,3 & 4,10 & 1,8 & 2926, & 1,3 & ,686 & 1654,5 & 18,4 & 1653 & 25 & 0 \\
\hline
\end{tabular}

ppm: partes por milhão; Rad: radical; err: erro; comm: comum; corr: corrigido; Disc: dircordância.
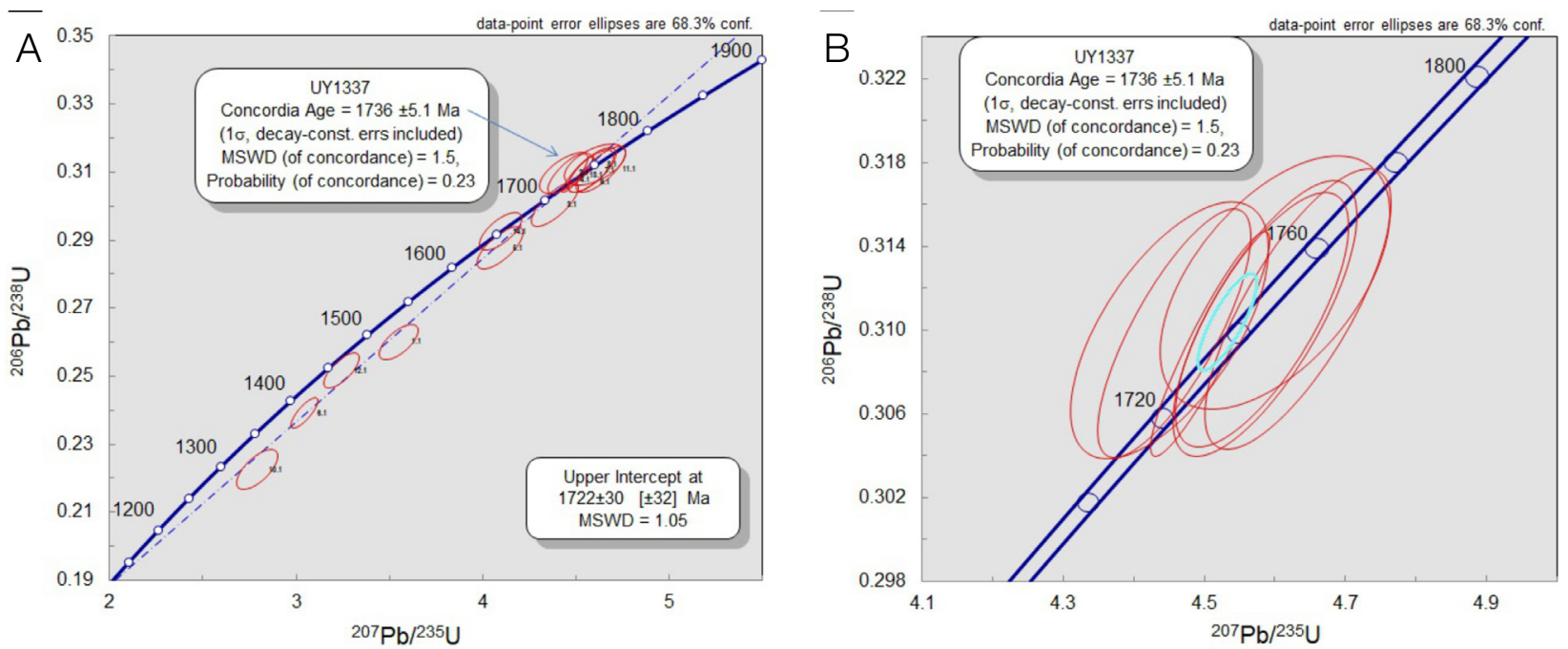

Figura 26. Diagramas concórdias das idades obtidas para o granulito félsico. (A) Diagrama concórdia mostrando o intercepto superior equivalente a $1.722 \pm 30 \mathrm{Ma}$; (B) diagrama mostrando idade concórdia de $1.736 \pm 5 \mathrm{Ma}$. 
com geração de silicatos ferromagnesianos, dominantemente desidratados (orto e clinopiroxênio), presença de feldspatos e ausência de muscovita primária. Durante a fase de deformação $\mathrm{F}_{2}$, desenvolve-se uma foliação plano-axial e paragênese metamórfica $\mathrm{M}_{2}$, com recristalização de biotita, clorita, sericita, epídoto e anfibólio (actinolita-tremolita), caracterizando retrometamorfismo para fácies xisto verde. A deformação $\mathrm{F}_{3}$ é posterior e, aparentemente, não está vinculada a metamorfismo, sendo apenas marcada por estruturas rasas, provavelmente associadas à tectônica andina.

As assinaturas químicas do granulito félsico revelam que o protólito foi gerado por um magmatismo cálcio-alcalino, metaluminoso a peraluminoso, magnesiano; enquanto o estudo geoquímico dos enclaves de granulito máfico mostra a existência de um magma básico associado. A geologia, a petrografia e a geoquímica, em conjunto, sugerem um ambiente convergente de arco magmático, com a ocorrência de mistura de magmas.

A análise U/Pb (SHRIMP) em zircão, obtida neste trabalho, revelou uma idade de cristalização de $1.736 \pm 5.1 \mathrm{Ma}$ do granulito félsico, considerada como a mais adequada para essas rochas devido aos valores semelhantes do intercepto superior e à idade concórdia e à natureza magmática dos zircões, sugeridas pelas razões $\mathrm{Th} / \mathrm{U}$ de 0,30 a 0,92 .

As idades apresentadas por Wörner et al. (2000), por meio dos métodos Ar/Ar em hornblenda com um platô de $982 \pm$ $2 \mathrm{Ma}$ e isócrona $\mathrm{Sm} / \mathrm{Nd}$ de $1.008 \pm 16 \mathrm{Ma}$, sugerem a atuação de um episódio termal regional, associado à evolução da Orogenia Grenvilliana-Sunsás, nas rochas granulíticas.

Com base nos dados obtidos neste trabalho, admite-se que a parte félsica do Granulito Uyarani é formada por rochas ortoderivadas, cujo protólito ígneo formou-se no estateriano, paleo-proterozoico, correlacionado cronologicamente ao Complexo Lomas Manechis, do terreno Paraguá, da Província Rondoniana-San Ignácio (Litherland et al., 1986; Bettencourt et al., 2010; entre outros). As idades mais jovens, apresentadas por Wörner et al. (2000), sugerem que esse fragmento crustal foi posteriormente retrabalhado pela Orogenia Sunsás durante o Toniano, no neoproterozoico, que afeta toda a borda oeste do Cráton Amazônico, da Colômbia a Bolívia, sugerindo que a conexão do Granulito Uyarani com o Cráton Amazônico está vinculada à aglutinação do supercontinente Rodínia.

\section{AGRADECIMENTOS}

Agradecemos à Coordenação de Aperfeiçoamento de Pessoal de Nível Superior (CAPES), pela concessão da bolsa; ao Grupo de Pesquisa em Evolução Crustal e Tectônica Guaporé, pelo apoio no tratamento das amostras para a realização das análises litoquímicas e geocronológicas; ao Instituto Nacional de Ciência e Tecnologia de Geociências da Amazônia (GEOCIAM), pelo auxílio financeiro no decorrer do trabalho de mestrado; à Universidad Mayor de San Andrés, pelo apoio ao acesso ao local de estudo, aos revisores pelas sugestões valiosas e aos editores pela minuciosa correção do manuscrito.

\section{REFERÊNCIAS}

Bahlburg, H., Hervé, F. (1997). Geodynamic evolution and tectonostratigraphic terranes of northwestern Argentina and northern Chile. Geological Society of America Bulletin, 109(7), 869-884.

Bettencourt, J. S., Leite Jr., W. B., Ruiz, A. S., Matos, R., Payolla, B. L., Tosdal, R. M. (2010). The Rondonian-San Ignacio Province in the SW Amazonian Cráton: an overview. Journal of South American Earth Sciences, 29, 28-46.

Boynton, W. V. (1984). Cosmochemistry of rare earth elements: meteorite studies. In: P. Henderson (Ed.). Rare Earth Element Geochemistry (v. 1, 63-114). Amsterdam: Elsevier Science.

Brito Neves, B. B. (2003). A saga dos descendentes de Rodínia na construção de Gondwana. Revista Brasileira de Geociências, 33, 77-88.

Cobbing, E. J., Ozard, J. M., Snelling, N. J. (1977). Reconnaissance geochronology of the crystalline basement rocks of the Coastal Cordillera of southern Peru. Geological Society of America Bulletin, 88, 241-246.

Cordani, U. G., Milani, E. J., Thomaz Filho, A., Campos, D. A. (2000). Tectonic Evolution of South America. $31^{\text {st }}$ International Geological Congress (9-40).

Coira, B., Davidson, J., Mpodozis, C., Ramos, V. A. (1982). Tectonic and magmatic evolution of the Andes of northern Argentina and Chile. Earth-Science Reviews, 18, 303-332.

Dalmayrac, B., Lancelot, J. R., Leyreloup, A. (1977). Twobillion-year granulites in the late Precambrian metamorphic basement along the southern Peruvian coast. Science, 198, 49-51.

Dalziel, I. W. D. (1997). Overview: Neoproterozoic-Paleozoic geography and tectonics: review, hypothesis, environmental speculations. Geological Society of America Bulletin, 109(1), 16-42.

Dalziel, I. W. D., Forsythe, R. D. (1985). Andean evolution and the terrane concept. Earth Science Series, 1, 565-581. 
De La Roche, H., Leterrier J., Grand Claude P., Marchal M. (1980). A classification of volcanic and plutonic rocks using R1-R2 diagram and major-element analyses. Its relationships with current nomenclature. Chemical Geology, 29(1), 183-210.

Debon, F., Le Fort, P. (1983). A chemical-mineralogical classification of common plutonic rocks and associations. Transactions of the Royal Society of Edinburgh: Earth Sciences, 73(3), 135-149.

Frost, B. R., Barnes, C. G., Collins, W. J., Arculus, R. J., Ellis, D. J., Frost, C. D. (2001). A geochemical classification of granitic rocks. Journal of Petrology, 42(11), 2033-2048.

Fuck, R. A., Brito Neves, B. B., Schobbenhaus, C. (2008). Rodinia descendants in South America. Precambrian Research, 160, 108-126.

Grohmann, C. H., Campanha, G. A. C., Soares Junior, A. V. (2011). OpenStereo: um programa livre e multiplataforma para análise de dados estruturais. XIII Simpósio Nacional de Estudos Tectônicos (24-26), Salvador: SBG.

Harris, N. B. W., Pearce, J. A., Tindle, A. G. (1986). Geochemical characteristics of collision-zone magmatism. Geological Society, 19, 67-81.

Irvine, I. N., Baragar, W. R. A. (1971). A Guide to the Chemical Classification of the Common Volcanics Rocks. Canadian Journal Earth Science, 8(5), 523-548.

Jaillard, E., Hérail, G., Monfret, T., Díaz-Martínez, E., Baby, P. (2000). Tectonic evolution of the Andes of Ecuador, Peru, Bolivia y Northernmost Chile. In: U. G. Cordani, E. J. Milani, A. Thomaz Filho, D. A. Campos (Eds.). Tectonic evolution of South America (481-559). Rio de Janeiro: SBG.

James, D. E. (1971). Plate tectonic model for the evolution of the Central Andes. Geological Society of American Bulletin, 82(12), 3325-3346.

Janoušek, V., Farrow, C. M., Erban, V. (2006). Interpretation of whole-rock geochemical data in igneous geochemistry: introducing Geochemical Data Toolkit (GCDkit). Journal of Petrology, 47(6), 1255-1259.

Lehmann, B. (1978). A Precambrian core sample from the Altiplano/Bolivia. Geologische Rundschau, 67(1), 270-278.

Litherland, M., Annells, R. N., Appleton, J. D., Berrangé, J. P., Bloomfield, K., Burton, C. C. J., Darbyshire, D. P. F., Fletcher, C. J. N., Hawkins, M. P., Klinck, B. A., Llanos, A.,
Mithcell, W. I., O'Connor, E. A., Pitfield, P. E. J., Power, G. E., Webb, B. C. (1986). The Geology and Mineral Resources of the Bolivian Precambrian Shield. British Geological Survey (n. 9). London: Her Majesty's Stationery Office.

Loewy, S. L., Connelly, J. N., Dalziel, I. W. D. (2004). An orphaned basement block: the Arequipa-Antofalla Basement of the central Andean margin of South America. Geological Society of America Bulletin, 116, 171-187.

Maniar, P. D., Piccoli, P. M. (1989). Tectonic discrimination of granitoids. Geological Society of America Bulletin, 101, 635-643.

McDonough, W. F., Sun, S. S. (1995). The composition of the Earth. Chemical Geology, 120, 223-253.

Miyashiro, A. (1974). Volcanic rock series in island arcs and active continental margins. American Journal of Science, 274, 321-355.

Monger, J. H. W., Price, R. A., Tempelman-Kluit, D. J. (1982). Tectonic accretion and the origin of two major metamorphic and plutonic welts in the Canadian Cordillera. Geology, 10(2), 70-75.

Mpodozis, C., Ramos, V. A. (1990). The Andes of Chile and Argentina. In: G. E. Ericksen, M. T. Cañas Pinochet, J. A. Reinemund (Eds.). Geology of the Andes and its relation to Hydrocarbon and Mineral Resources (11, 59-90). Houston: Circum Pacific Council for Energy and Mineral Resources.

Mullen, E. D. (1983). MnO/TiO2/P2O5: a minor element discriminant for basaltic rocks of oceanic environments and its implications for petrogenesis. Earth and Planetary Science Letters, 62(1), 53-62.

Nakamura, K. (1977). Volcanoes as a possible indicator of tectonic stress orientation: principle and proposal. Journal of Volcanology and Geothermal Research, 2(1), 1-16.

Oliveira J. R., Ruiz A. S., Souza M. Z. A., Salinas R. M. (2015). Análise estrutural e metamórfica das rochas do Cerro Uyarani: janela tectônica pré-cambriana no altiplano boliviano. XV Simpósio Nacional de Estudos Tectônicos (15, 55-58).

Pearce, J. A., Cann, J. R. (1973). Tectonic setting of basic volcanic rocks investigated using trace element analyses. Earth and Planetary Science Letters, 19(2), 290-300.

Pearce, J. A., Harris, N. B. W., Tindle, A. G. (1984). Trace element discrimination diagrams for the tectonic interpretation of granitic rocks. Journal of Petrology, 25(4), 956-983. 
Ramos, V. A. (1986). El diastrofismo ocolóyico: un ejemplo de tectónica de colisión durante el Eopaleozoico en el noroeste argentino. Revista Institucional de Ciencias Geologicas, 6, 13-28.

Ramos, V. A. (1988). Tectonics of the Late Proterozoic-Early Paleozoic: a collisional history of Southern South America. Episodes, 11(3), 168-174.

Ramos, V. A. (2008). The basement of the Central Andes: the Arequipa and related terranes. Annual Review of Earth and Planetary Sciences, 36, 289-324.

Ramos, V. A. (2010). The Grenville-Age Basement of the Andes. Journal of South American Earth Sciences, 29, 77-91. DOI: 10.1016/j.jsames.2009.09.004.

Rapela, C. W., Pankhurst, R. J., Casquet, C., Fanning, C. M., Baldo, E. G., González Casado, J. M., Galindo, C., Dahlquist, J. (2007). The Río de la Plata craton and the assembly of SW Gondwana. Earth-Science Reviews, 83, 49-82.
Tosdal, R. M. (1996). The Amazon-Laurentian connection as viewed from Middle Proterozoic rocks in the central Andes, western Bolivia and northern Chile. Tectonics, 15(4), 827-842.

Troeng, B., Soria, E., Claure, H., Mobarec, R., Murillo, F. (1994). Descubrimiento de Basamento Precambrico en La Cordillera Occidental Altiplano de los Andes Bolivianos. XI Congreso Geologico Boliviano (231-236). La Paz: CGB.

Wood, D. A. (1980). The application of a Th-Hf-Ta diagram to problems of tectonomagmatic classification and to establishing the nature of crustal contamination of basaltic lavas of the British Tertiary volcanic province. Earth and Planetary Science Letters, 50, 11-30.

Wörner, G., Lezaun, J., Beck, A., Heber, V., Lucassen, F., Zinngrebe, E., Rössling, R., Wilke, H. G. (2000). Precambrian and Early Paleozoic evolution of the Andean basement at Belen (northern Chile) and Cerro Uyarani (western Bolivia Altiplano). Journal of South American Earth Sciences, 13(8), 717-737. 